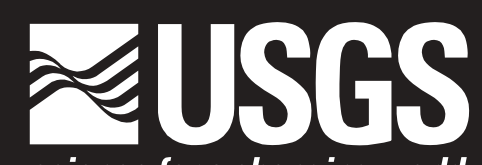

Prepared in cooperation with the city of Rochester, Minnesota

\title{
Ground-Water Recharge and Flowpaths Near the Edge of the Decorah-Platteville-Glenwood Confining Unit, Rochester, Minnesota
}

Water-Resources Investigations Report 00-4215

U.S. Department of the Interior

U.S. Geological Survey 
U.S. Department of the Interior

U.S. Geological Survey

\section{Ground-Water Recharge and Flowpaths Near the Edge of the Decorah-Platteville-Glenwood Confining Unit, Rochester, Minnesota}

By Richard J. Lindgren

Water-Resources Investigations Report 00-4215

Prepared in cooperation with the City of Rochester, Minnesota 


\section{U.S. Department of the Interior}

\section{Gale A. Norton, Secretary}

\section{U.S. Geological Survey}

Charles G. Groat, Director

Use of trade, product, or firm names in this report is for identification purposes only and does not constitute endorsement by the U.S. Government.

Mounds View, Minnesota, 2001

For additional information write to:

District Chief

U.S. Geological Survey, WRD

2280 Woodale Drive

Mounds View MN 55112

Copies of this report can be purchased from:

\section{U.S. Geological Survey}

\section{Branch of Information Services}

\section{Box 25286}

Federal Center

Denver CO 80225

For more information on the USGS in Minnesota, you may connect to the Minnesota District home page at http://mn.water.usgs.gov

For more information $n$ all USGS reports and products (including maps mages, and computerized data), call 1-888-ASK-USGS

Water-Resources Investigations Report 00-4215 


\section{CONTENTS}

Abstract

Introduction

Purpose and Scope $\quad 4$

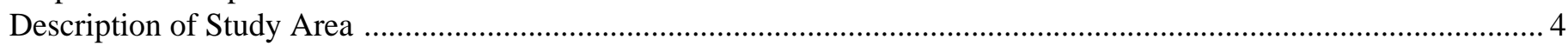

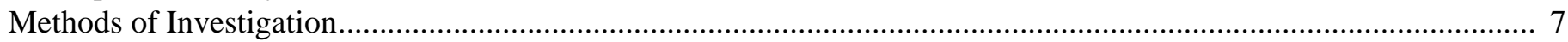

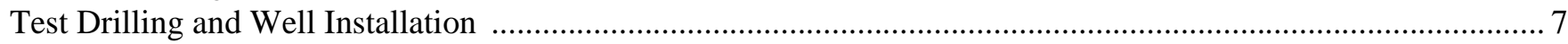

Water Levels and Stream Discharge

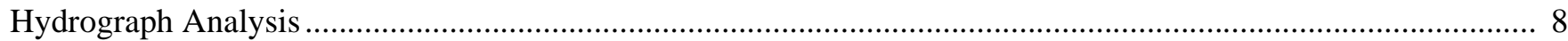

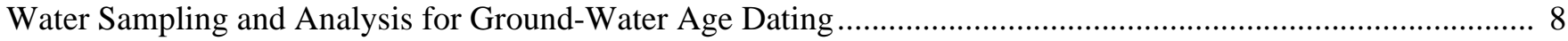

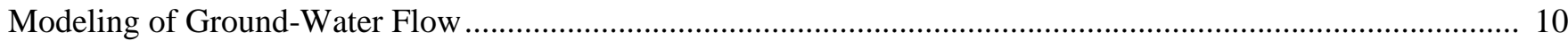

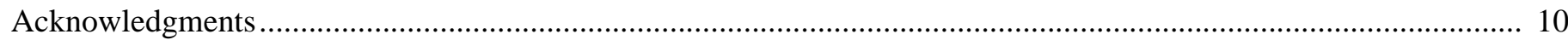

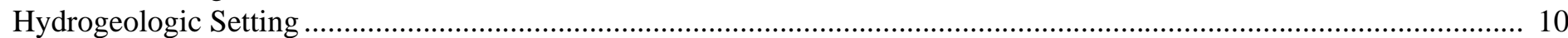

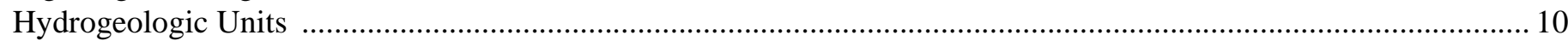

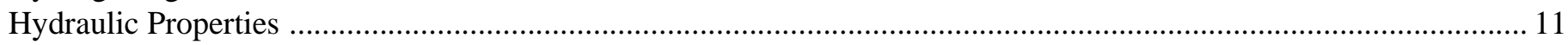

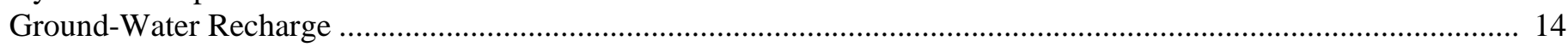

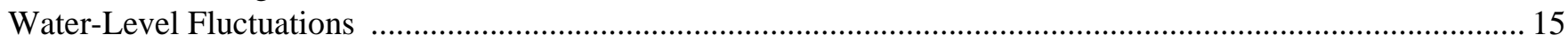

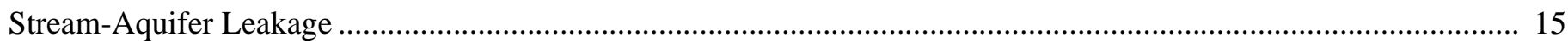

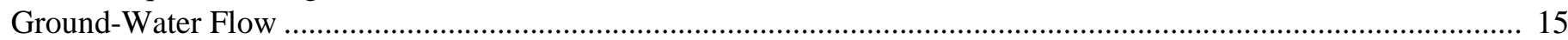

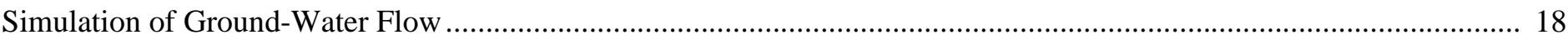

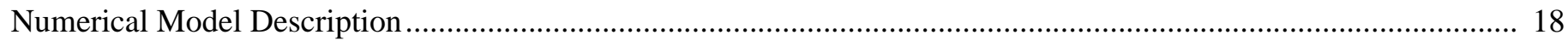

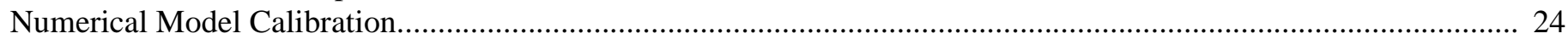

Sensitivity Analysis 25

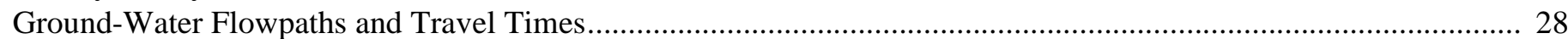

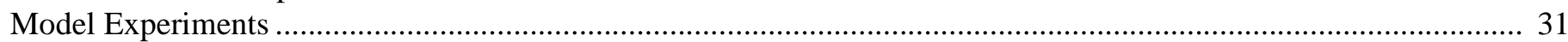

Results for the cross-sectional model experiments, Rochester area, Minnesota 36

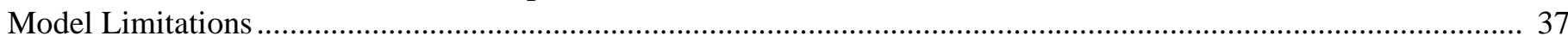

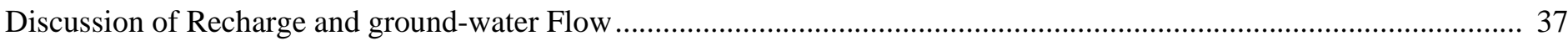

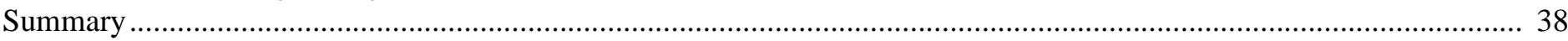

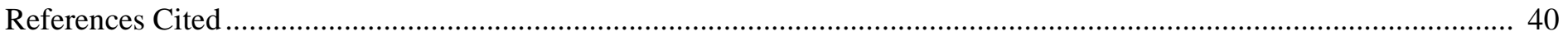

\section{ILLUSTRATIONS}

Figure 1. Map showing location of study area, observation wells drilled for this study, biweekly observation wells, and bedrock hydrogeology, Rochester area, Minnesota

Figure 2. Diagram showing generalized hydrogeologic column of regional aquifers and confining units Olmsted County, Minnesota

Figure 3. Map showing trace of hydrogeologic section A - $\mathrm{A}^{\prime}$, locations of wells along flowpath, stream stage and streamflow measurement sites, potentiometric surface of the St. Peter-Prairie du Chien-Jordan aquifer, February through March 1995, and ground-water divide, Rochester area, Minnesota......

Figure 4. Hydrogeologic section A - A' showing hydrogeologic units, measured hydraulic heads October and November 1998, equipotential lines, and direction of ground-water flow, Rochester area, Minnesota.....

Figure 5. Map showing bedrock hydrogeology and locations of wells sampled for chlorofluorocarbon analysis, Rochester

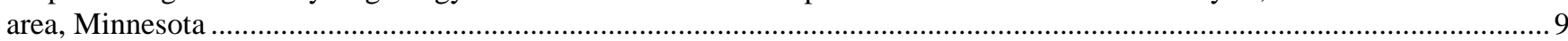

Figure 6. Water levels in observation wells during 1997-99in the St. Peter-Prairie du Chien-Jordan aquifer, Rochester area, Minnesota 12

Figures 7a-11. Hydrogeologic section showing:

7a. Model layers, corresponding hydrogeologic units, and simulated areal recharge zones, Rochester area, Minnesota..........20

7b. Model layers, corresponding hydrogeologic units, and simulated areal recharge zones near edge of confining units, Rochester area, Minnesota

Figures 8a-11. Hydrogeologic sections showing:

8a. Model layers, corresponding hydrogeologic units, and simulated equipotential lines, Rochester area, Minnesota

8 b. Model layers, corresponding hydrogeologic units, and simulated equipotential lines near edge of confining units, Rochester area, Minnesota 


\section{ILLUSTRATIONS--CONTINUED}

9a. Hydrogeologic units and flowpath-line plot representing the movement of recharge water derived from infiltration of precipitation through the aquifer system, Rochester area, Minnesota.

9b. Hydrogeologic units and flowpath-line plot representing the movement of recharge water derived from infiltration of precipitation through the aquifer system near edge of confining units, Rochester area, Minnesota.....

10. Hydrogeologic units and flowpath-line plot representing the movement of water originating near the eastern model boundary through the aquifer system, Rochester area, Minnesota

11. Hydrogeologic units and flowpath-line plot representing the movement of water originating near the top of layer 3 through the aquifer system, Rochester area, Minnesota

\section{TABLES}

Table 1. Estimated ground-water recharge rates to the aquifer system based on hydrograph analysis, Rochester area, Minnesota....... 16

Table 2. Comparison of ground-water recharge rates to the aquifer system derived from hydrograph analysis, chlorofluorocarbon age-dating, and numerical ground-water-flow model analysis, Rochester area, Minnesota...

Table 3. Initial and best-fit calibrated values of hydraulic properties used in the cross-sectional model of the aquifer system, Rochester area, Minnesota

Table 4. Initial and best-fit calibrated values of areal recharge rate used in the cross-sectional model of the aquifer system, Rochester area, Minnesota

Table 5. Simulated water budget from the cross-sectional model of the aquifer system, Rochester area, Minnesota

Table 6. Simulated leakage between model layers from the cross-sectional model of the aquifer system, Rochester area, Minnesota

Table 7. Sensitivity of simulated hydraulic heads and flows in the aquifer system to changes in values of hydrogeologic properties or conditions in steady-state simulation, Rochester area, Minnesota

Table 8. Results for the cross-sectional model experiments, Rochester area, Minnesota 


\section{Ground-Water Recharge and Flowpaths Near the Edge of the Decorah-Platteville-Glenwood Confining Unit, Rochester, Minnesota}

\section{By Richard J. Lindgren}

\section{ABSTRACT}

The primary source of ground water for the city of Rochester, Olmsted County, southeastern Minnesota is the St. Peter-Prairie du Chien-Jordan aquifer. Based on results of a previous U.S. Geological Survey investigation in the Rochester area, relatively high rates of areal recharge to the St. Peter-Prairie du Chien-Jordan aquifer occur along the edge of the overlying Decorah-Platteville-Glenwood confining unit. The primary source of water to the zone of increased recharge along the edge of the confining unit is the upper carbonate aquifer.

Ground-water recharge rates to the St. Peter-Prairie du Chien-Jordan aquifer during all of 1998 ranged from 1.9 to $25.5 \mathrm{in} . / \mathrm{yr}$ (inches per year). Recharge rates were greatest near the edge of the Decorah-Platteville-Glenwood confining unit and least where the confining unit is thick and is overlain by the upper carbonate aquifer (mean of $2.0 \mathrm{in} . / \mathrm{yr}$ ). Recharge rates downslope from the edge of the confining unit were greatest to the St. Peter on the slope entering the main South Fork Zumbro River Valley. Results of groundwater age dating using chlorofluorocarbons (CFCs) indicated recharge dates ranging from (1) the mid-1950's to the early 1990's for the St. Peter, (2) the late 1960's to approximately 1990 for the Prairie du Chien, and (3) the early to mid-1950's for the Jordan.

Cross-sectional model simulations indicated that most of the areal recharge entering the aquifer system through the upper carbonate aquifer discharges from springs and seeps. Of the $2.28 \mathrm{ft}^{3} / \mathrm{s}$ (cubic feet per second) of areal recharge that enters the upper carbonate aquifer, $2.23 \mathrm{ft}^{3} / \mathrm{s}$ is discharged from the aquifer by springs and seeps. Results indicate that areal recharge to the upper Prairie du Chien moves primarily westward and discharges to Bear Creek.

Areal recharge rates derived from hydrograph analysis, CFC age-dating, and cross-sectional model analysis were much greater to the St. Peter downslope from the edge of the Decorah-Platteville-Glenwood confining unit $(25.5,35.3$, and 23.75 in./yr, respectively) than occurs to the Prairie du Chien in any hydrogeologic setting. The model-simulated discharge from springs and seeps in the lower part of the upper carbonate aquifer represents a potential source of water of $33 \mathrm{in./yr}$ to the St. Peter unit, similar to the estimated areal recharge rates derived from hydrograph analysis and CFC age-dating.

The water withdrawn by pumped wells or discharged to Bear Creek is derived predominantly from areal recharge near the edge of the Decorah-Platteville-Glenwood confining unit $\left(0.47 \mathrm{ft}^{3} / \mathrm{s}\right)$, rather than from water that has leaked downward through the Decorah unit $\left(0.03 \mathrm{ft}^{3} / \mathrm{s}\right)$. Model simulated discharge through springs and seeps in the lower part of the upper carbonate aquifer $\left(0.21 \mathrm{ft}^{3} / \mathrm{s}\right)$ represents a potential source of water to the St. Peter-Prairie du ChienJordan aquifer.

\section{INTRODUCTION}

The primary source of ground water for the city of Rochester, Olmsted County, southeastern Minnesota (fig. 1), is the St. Peter-Prairie du Chien-Jordan aquifer. Based on results of a previous U.S. Geological Survey (USGS) investigation in the Rochester area (Delin, 1990), relatively high rates of recharge to the St. Peter-Prairie du Chien-Jordan aquifer from infiltration of precipitation and water discharged from springs and seeps, hereinafter termed areal recharge, occur along the edge of the overlying Decorah-Platteville-Glenwood confining unit (figs. 1 and 2). Increased areal recharge along the edge of the Decorah-Platteville-Glenwood confining unit is the likely cause of highs in the potentiometric surface of regional aquifers throughout southeastern Minnesota, which are displaced from topographic highs (Delin and Woodward, 1984). Based on analysis by use of a numerical ground-water-flow model, areal recharge to the St. Peter-Prairie du Chien-Jordan aquifer near the edge of the Decorah-Platteville-Glenwood confining unit in the Rochester area is $13 \mathrm{in./yr}$, compared to a rate as low as $0.1 \mathrm{in} . / \mathrm{yr}$ where the confining unit is present. A rate of $5 \mathrm{in} . / \mathrm{yr}$ was determined where the confining unit is absent (Delin, 1990).

The St. Peter-Prairie du Chien-Jordan aquifer is highly susceptible to contamination where the Decorah- 


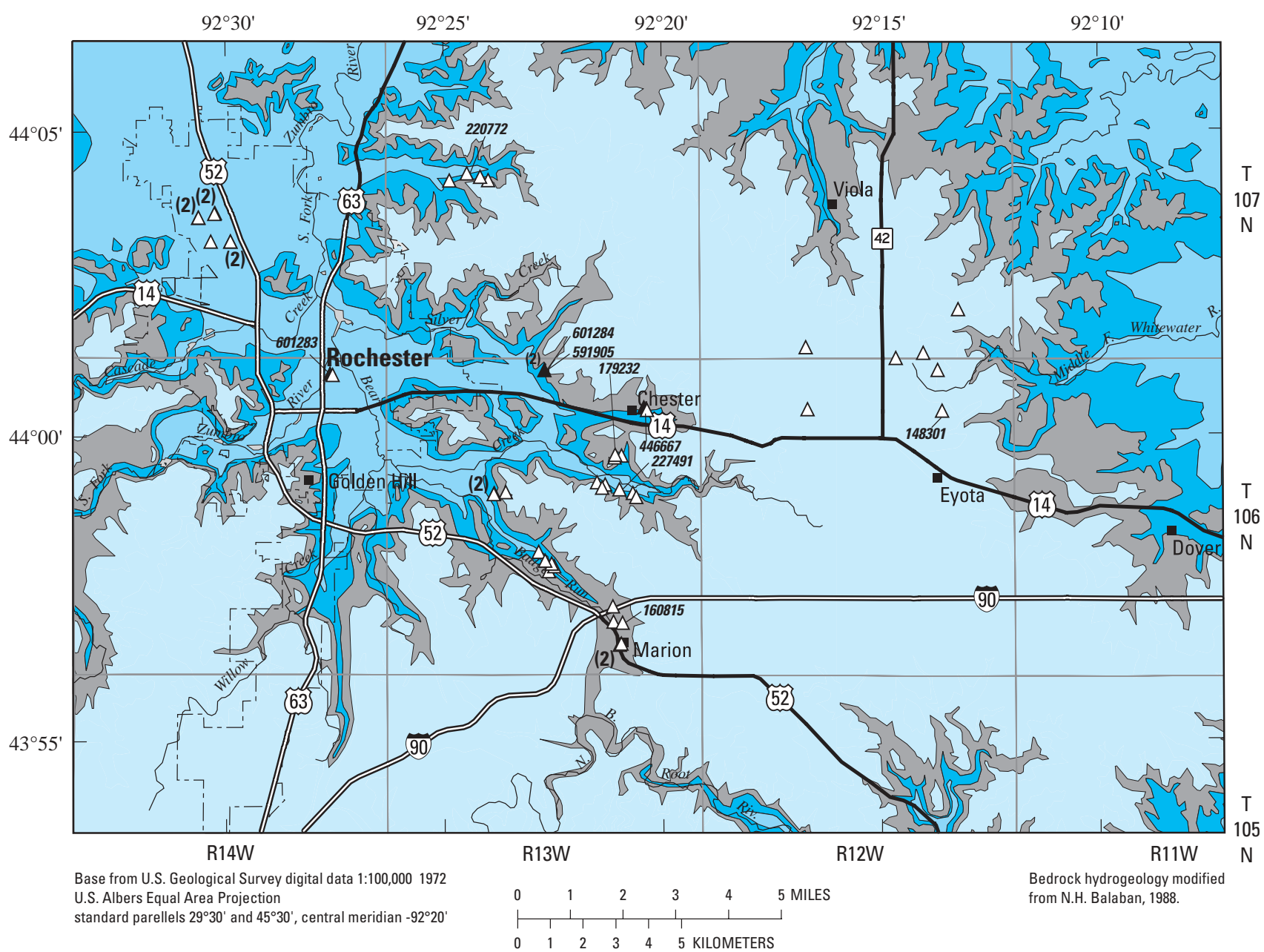

\section{EXPLANATION}
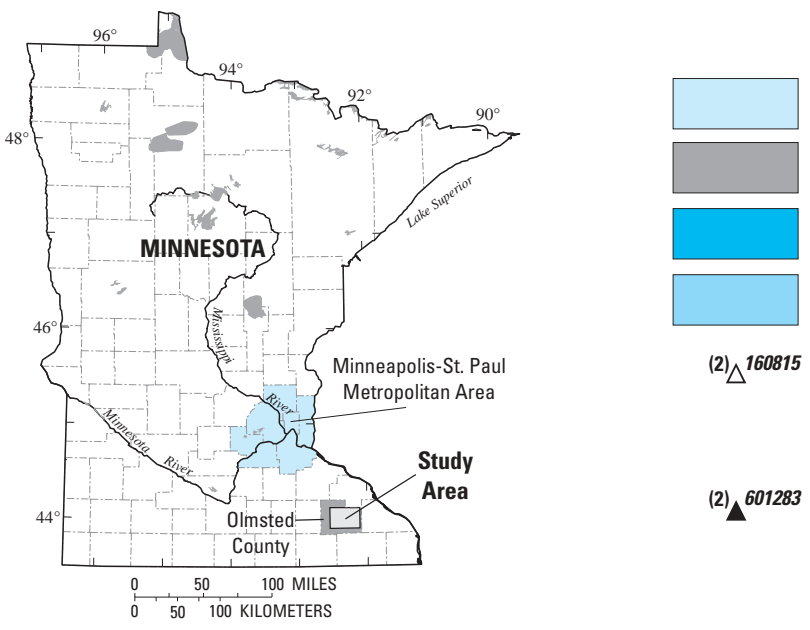

Upper carbonate aquifer

Decorah-Platteville-Glenwood confining unit

St. Peter unit of the St. Peter-Prairie du Chien-Jordan aquifer

Prairie du Chien unit of the St. Peter-Prairie du Chien-Jordan aquifer

${ }^{(2)} \triangle^{160815}$ Biweekly observation well. Number indicates Minnesota unique number for wells with hydrographs shown in figure 6 . Number in parentheses indicates nested wells

(2) $\Lambda^{601283}$ Observation well drilled for this study. Number indicates Minnesota unique number for wells with hydrographs shown in figure 6 .

Number in parentheses indicates nested wells

Figure 1. Location of study area, observation wells drilled for this study, biweekly observation wells, and bedrock hydrogeology, Rochester area, Minnesota. 


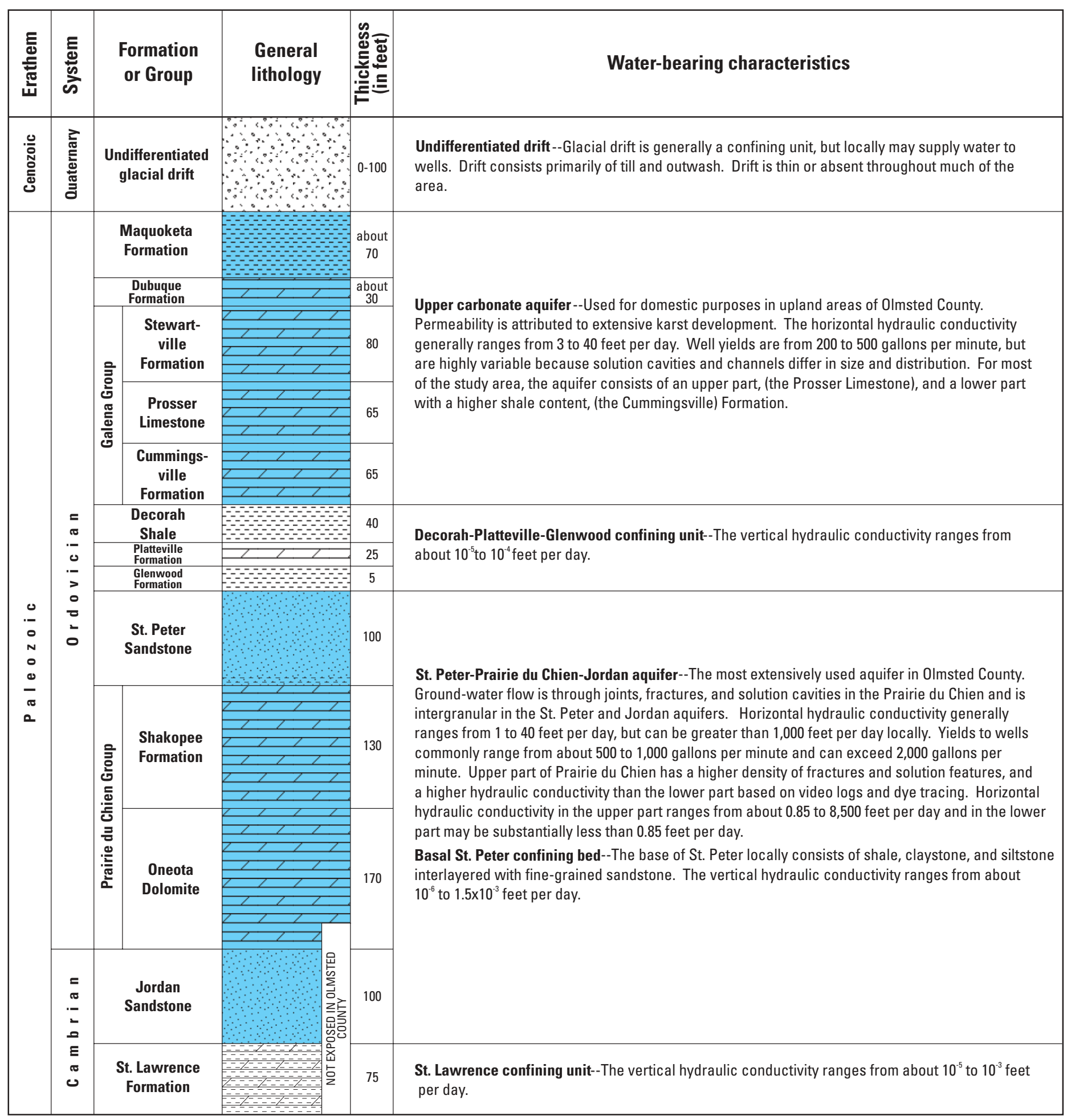

EXPLANATION

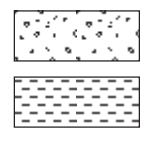

Till, sand, and gravel

Shale

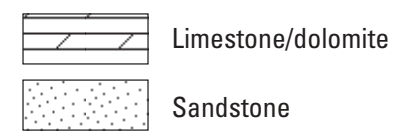

Aquifer

Figure 2. Generalized hydrogeologic column of regional aquifers and confining units Olmsted County, Minnesota (geology modified from N.H. Balaban, 1988, water-bearing characteristics modified from G.N. Delin, 1990). 
Platteville-Glenwood confining unit is absent. Smith and Nemetz (1996) reported greater concentrations of nitrite-plus-nitrate nitrogen, chloride, and tritium in water from the St. PeterPrairie du Chien-Jordan aquifer in areas where the confining unit is absent compared to areas where the confining unit is present near Rochester. Nitrite-plus-nitrate nitrogen and chloride are commonly used as indicators of human activities that affect ground water.

The primary source of water to the zone of increased areal recharge along the edge of the Decorah-PlattevilleGlenwood confining unit in the Rochester area is the upper carbonate aquifer, which underlies the uplands away from the stream valleys. The upper carbonate aquifer has large secondary permeability and has been affected by widespread contamination from agricultural chemicals. There is concern that water withdrawn from the deeper St. Peter-Prairie du Chien-Jordan aquifer may become contaminated by water that originated in the overlying upper carbonate aquifer. Ground water pumped from wells in the city of Rochester may obtain as much as 50 percent of their water supplies from water entering the aquifer in the zone of increased areal recharge along the edge of the confining unit (Delin, 1990).

Management of ground-water resources is critical for Rochester Public Utilities (RPU), which regulates Rochester municipal ground-water use. In addition, the Minnesota Department of Natural Resources (MDNR) issues permits for groundwater use within the State and is promoting conservation and efficient use of water. Additional information is needed by the RPU and the MDNR on areal recharge rates, sources of water to the St. Peter-Prairie du Chien-Jordan aquifer, and flowpaths in the ground-water system to better manage ground-water resources in the Rochester area.
A zone of increased areal recharge along the edge of the Decorah-Platteville-Glenwood confining unit is likely in many areas in southeastern Minnesota. In addition, the topography and structure of the Ordovicianage rocks in southeastern Minnesota make this a favorable location to estimate varying areal recharge rates across a broad spectrum of hydrogeologic settings. The distribution and rates of areal recharge along the edge of confining units is poorly understood.

The USGS, in cooperation with the city of Rochester, conducted a 3-year study (October 1996-September 1999) to quantify areal recharge rates along the edge of the Decorah-Platteville-Glenwood confining unit in the Rochester area. The study also included an analysis of areal recharge rates in areas where the confining unit is thick and where the confining unit is absent. A numerical steady-state cross-sectional ground-water-flow model of the ground-water system in the Rochester area was constructed to test concepts of increased areal recharge and to evaluate ground-water flowpaths along the edge of the confining unit.

\section{PURPOSE AND SCOPE}

This report describes results of field data collection during 1996-99, sources and types of data used in constructing a numerical cross-sectional ground-water-flow model, the model calibration process, and results of model simulations. Areal recharge rates were estimated for three hydrogeologic settings where differing rates of areal recharge were expected. The three hydrogeologic settings were (1) near the edge of the Decorah-Platteville-Glenwood confining unit, (2) where the confining unit is thick and is overlain by the upper carbonate aquifer, and (3) where the confining unit is absent and the Prairie du Chien unit of the St. Peter-Prairie du Chien-Jordan aquifer is the uppermost bedrock unit (fig. 1). The scope of the report includes a discussion of estimated ground-water recharge rates for the three hydrogeologic settings using hydrograph analysis and chlorofluorocarbon (CFC) age-dating methods. Areal recharge, ground-water flow, and discharge along a ground-water flowpath are analyzed, using a numerical cross-sectional ground-waterflow model. The trace of section and hydrogeologic section A-A', representing the hydrogeology along a flowpath from the regional groundwater divide for the St. Peter-Prairie du Chien-Jordan aquifer, located east of Rochester, westward to the South Fork Zumbro River, are shown in figures 3 and 4, respectively.

The term ground-water system, as used in this report, refers to the sequence of hydrogeologic units shown in figure 4 from land surface to the St. Lawrence confining unit. For the purposes of this report, the St. Peter-Prairie du Chien-Jordan aquifer is composed of three distinct units. Similarly, the Decorah-PlattevilleGlenwood confining unit is composed of three distinct units. Throughout the report, the individual units of the aquifer (St. Peter, Prairie du Chien, and Jordan) or the confining unit (Decorah, Platteville, and Glenwood) are referred to, as well as the entire aquifer or confining unit.

\section{DESCRIPTION OF STUDY AREA}

The study area includes approximately $325 \mathrm{mi}^{2}$ in Olmsted County in southeastern Minnesota (fig. 1). The study area is drained by the South Fork Zumbro, Whitewater, and Root Rivers, which are tributaries of the Mississippi River. Topography is rolling to undulating in upland areas and steep near streams and drainage ways. Land use is primarily for agriculture, including dairy farming, hog production, and corn and soybean cropping. The City of Rochester is growing rapidly over the zone along the edge of the Deco- 

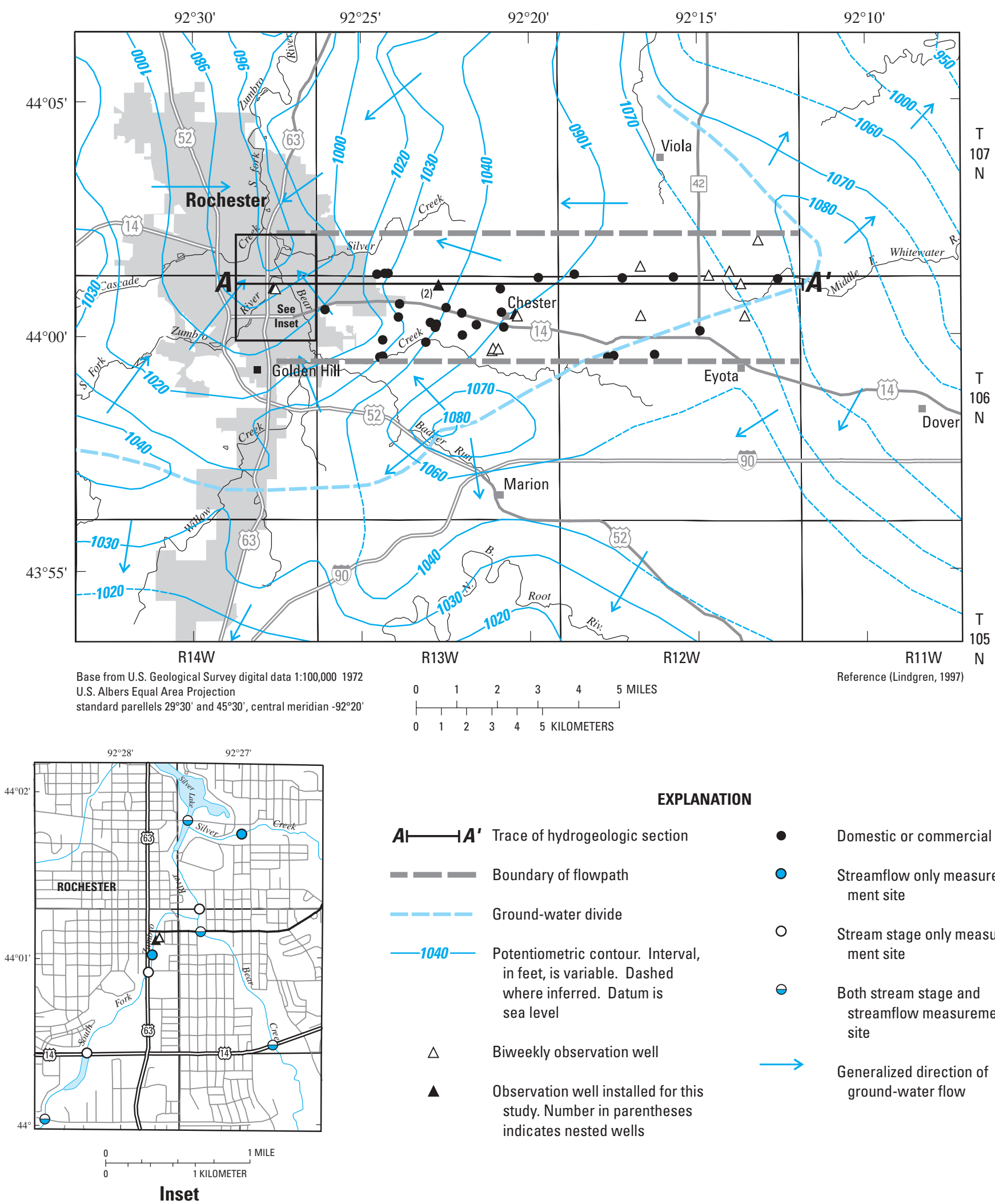

EXPLANATION

$\begin{array}{lll}A \longmapsto & \bullet & \text { Domestic or commercial well } \\ \text { Boundary of flowpath } & 0 & \begin{array}{c}\text { Streamflow only measure- } \\ \text { ment site }\end{array}\end{array}$

$=-1$ Ground-water divide

—1040_ Potentiometric contour. Interval, in feet, is variable. Dashed where inferred. Datum is sea level

$\triangle \quad$ Biweekly observation well

- Observation well installed for this study. Number in parentheses indicates nested wells
○ Stream stage only measurement site

$\ominus \quad$ Both stream stage and streamflow measurement site

Generalized direction of ground-water flow

Figure 3. Trace of hydrogeologic section A - A', locations of wells along flowpath, stream stage and streamflow measurement sites, potentiometric surface of the St. Peter-Prairie du Chien-Jordan aquifer, February through March 1995, and ground-water divide, Rochester area, Minnesota. 


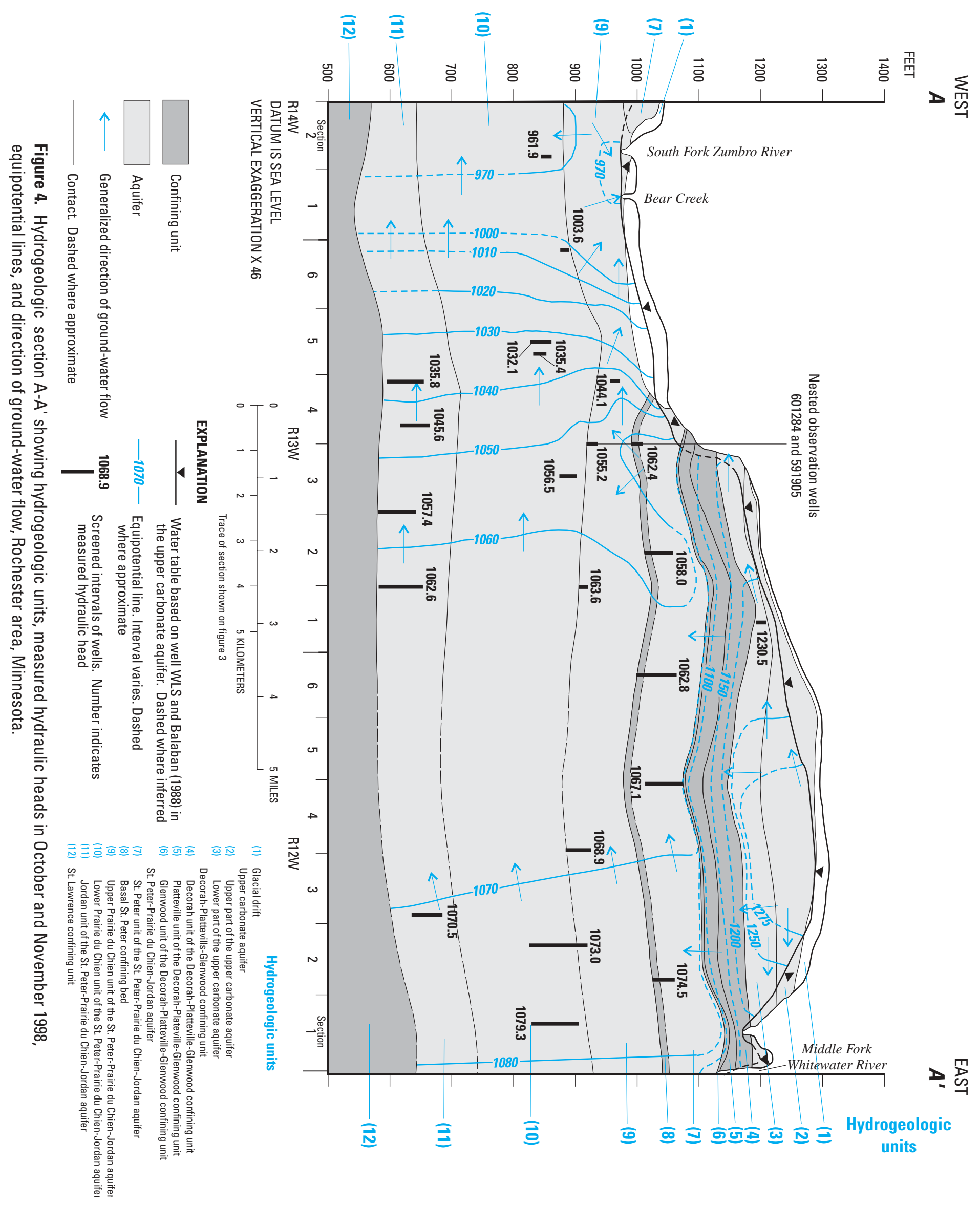


rah-Platteville-Glenwood confining unit where increased recharge is thought to occur. Mean annual precipitation is 27.5 in. (Baker and Kuehnast, 1978).

\section{METHODS OF INVESTIGATION}

Previously collected data on the hydrogeology and hydraulic properties of the aquifer system near Rochester were compiled from a variety of sources including water-well logs, geologic maps, State and Federal data bases, and published reports. The results of recent work investigating the hydraulic properties of the Prairie du Chien in southeastern Minnesota were obtained from Tony Runkel of the Minnesota Geological Survey (MGS). Additional test drilling and well installation, measurements of water levels and stream discharge, and water sampling for ground-water age-dating were done for this study. A numerical cross-sectional ground-water-flow model was constructed using information from water-well logs and geologic maps along a selected flowpath.

\section{Test Drilling and Well Installation}

Water-well and test-hole logs were obtained from the MGS County Well Index for Olmsted County and from the U.S. Geological Survey GroundWater Site Inventory data base.

Hydrogeologic information was compiled from Balaban (1988), Delin (1990), and recent unpublished work in southeastern Minnesota (Tony Runkel, Minnesota Geological Survey, written commun., 1999).

Four, 2-inch-diameter, observation wells were installed during November 1997 at three sites (fig. 1). Three of the wells were screened in the Prairie du Chien. The fourth well, screened in the St. Peter, was installed near one of the other wells, creating a nested pair of wells. The hydrogeologic setting for two of the sites was at the edge of the Decorah-Platteville-Glenwood confining unit and for the third site was in
Rochester where the confining unit is absent and the Prairie du Chien is the uppermost bedrock unit. The site with the pair of nested wells (wells 601284 and 591905) is located where the St. Peter is the uppermost unit and downslope from the edge of the Decorah unit of the Decorah-Platteville-Glenwood confining unit in the zone of increased recharge. The nested wells were used to determine differences in hydraulic heads between the St. Peter and Prairie du Chien units of the St. Peter-Prairie du Chien-Jordan aquifer.

\section{Water Levels and Stream Discharge}

The four observation wells installed for this study were instrumented with pressure transducers to provide hourly water-level measurements. Domestic and commercial wells completed in the bedrock aquifers were also used extensively for water-level measurements. Water levels were measured biweekly, or monthly during the winter months, in 35 domestic and commercial supply wells and 7 industrial, 2-inch-diameter, observation wells (fig. 1). There are 42 biweekly observation wells.

The biweekly observation wells are located predominantly near the edge of the Decorah-Platteville-Glenwood confining unit in differing hydrogeologic settings (fig. 1). Three of the 42 wells are located near the edge of the confining unit on slopes entering the main South Fork Zumbro River Valley. Nineteen of the wells are located on side slopes entering tributary valleys to the South Fork Zumbro River Valley. Five of the wells are located in the Marion area near the head of a tributary valley. Seven of the wells are located east of the edge of the confining unit, where the confining unit is thick and is overlain by the upper carbonate aquifer. Eight of the wells, including the seven industrial observation wells, are located west of the edge of the confining unit in the city of
Rochester where the Prairie du Chien is the uppermost bedrock unit.

The biweekly observation wells are open to differing units of the St. PeterPrairie du Chien-Jordan aquifer. Seven of the 39 wells are screened in the St. Peter, 24 in the Prairie du Chien, 7 in the Jordan, and 1 in both the Prairie du Chien and the Jordan. The water-level information was used to calculate areal recharge rates to the aquifers using hydrograph analysis and to quantify differences in areal recharge rates in different hydrogeologic settings near and distant from the edge of the Decorah-Platteville-Glenwood confining unit.

Water levels were measured in 29 domestic and commercial supply wells during October and November 1998, in addition to the biweekly observation wells. The wells were located within a 3-mi wide area representing a flowpath from the regional ground-water divide for the St. PeterPrairie du Chien-Jordan aquifer east of Rochester westward to the South Fork Zumbro River (fig. 3). The 29 domestic and commercial supply wells, 12 biweekly observation wells, and 4 observation wells installed for this study are included in this set of 45 wells, hereinafter termed flowpath wells. The flowpath wells included wells near and distant from the edge of the confining unit in different hydrogeologic settings. The flowpath wells are screened in the glacial drift (2 wells), in the upper carbonate aquifer ( 2 wells), in the St. Peter ( 9 wells), in the Prairie du Chien ( 24 wells), in the Jordan (7 wells), and in both the Prairie du Chien and the Jordan (1 well) . Few domestic or commercial wells completed in the upper carbonate aquifer were available for water-level measurements. New supply wells are prohibited from being completed in this aquifer due to concerns about contamination from land and surfacewater sources, and many have been abandoned and sealed (Terry Lee, 
Olmsted County Environmental

Resource Services, oral commun., 1997). Water-level data from 22 of the flowpath wells were used to calibrate a numerical cross-sectional model.

Stream-stage measurements were made during November 1998 at five sites on the South Fork Zumbro River and two sites on Bear Creek at the western end of the flowpath. Streamflow measurements were also made during November 1998 at three sites on the South Fork Zumbro River and at two sites on Bear Creek. The streamflow measurements were used to derive estimates of stream-aquifer leakage. The streamflow measurements made on the South Fork Zumbro River, however, were not sufficiently accurate to estimate stream-aquifer leakage and could not be used. The stream stages, and streamflow measurements made on Bear Creek, were used in the construction and calibration of a numerical cross-sectional ground-water-flow model.

The altitudes of all water-level measurement points were determined by surveying done by the USGS (Greg Payne, written commun., 1998). Altitudes of measuring points were measured with a precision of $\pm 0.1 \mathrm{ft}$.

\section{Hydrograph Analysis}

Ground-water recharge rates to the three units comprising the St. PeterPrairie du Chien-Jordan aquifer were estimated from water-level measurements of the biweekly observation wells and the four observation wells installed for this study. Areal recharge to the St. Peter and Prairie du Chien occurs where the Decorah-PlattevilleGlenwood confining unit is absent and the St. Peter and Prairie du Chien units are the uppermost bedrock units. Ground-water recharge rates were estimated using the method of hydrograph analysis described by Rasmussen and Andreasen (1959). The method assumes that all water-level rises in the well result from areal recharge from infiltration of precipitation or from leakage through overlying hydrogeologic units. Recharge is equivalent to the water-level rise over a given period of time multiplied by the aquifer specific yield. Specific yield was assumed to be approximately equal to porosity. Porosity values of 0.25 for the St. Peter and 0.1 for the Prairie du Chien and Jordan were used in the recharge calculations. The porosity value used for the Jordan was less than that for the St. Peter because in the Rochester area the Jordan includes a feldspathic facies of much lower hydraulic conductivity and porosity than the quartzose facies (Runkel, 1996). Recharge to all three units of the St. Peter-Prairie du ChienJordan aquifer occurs by leakage through the Decorah-Platteville-Glenwood confining unit where it overlies the aquifer.

\section{Water Sampling and Analysis for Ground-Water Age Dating}

Ground-water samples were collected during October 1997 from 34 wells screened in the St. Peter-Prairie du Chien-Jordan aquifer. Water samples were collected from most of the biweekly observation wells and a few other wells. The water samples were analyzed for tritium concentrations to determine the approximate age of the water to determine which wells to sample for analysis of CFC concentrations.

The CFC age-dating technique for ground water as described by Busenberg and Plummer (1992) and Dunkle and others (1993) was used to estimate ground-water recharge rates. Groundwater samples were collected during May 1998 from six of the biweekly observation wells and from three of the four observation wells installed for this study (fig. 5). All the wells were open to the St. Peter-Prairie du ChienJordan aquifer. Recharge dates of ground water at screened depths below the water table were estimated from measured concentrations of CFCs
(CFC-11, CFC-12, and CFC-13) in the ground-water samples collected during May 1998. The year of recharge for each sample was determined by matching the measured CFC concentration in the sample, converted to an equivalent partial pressure, with the appropriate year in the historical record of CFC partial pressure in the atmosphere (Busenberg and others, 1993). Overall uncertainties in estimated recharge dates between 1960 and 1990 caused by uncertainties in recharge temperatures, and by analytical uncertainties, are estimated to be on the order of \pm 2 years. Recharge dates before 1960 and after 1990 have larger uncertainties. For this study, the best results were obtained using the CFC-12 concentrations.

The downward vertical groundwater velocity gradient at each sampled well was estimated as a function of the recharge date of the ground water and the depth of the screened interval below the water table. Ideally, water samples from multiple nested wells at a site are used to determine ground-water age-depth profiles to estimate the ground-water velocity gradient. For this study, however, nested wells were available at only one site. The average porosity of the screened aquifer unit was then multiplied by the ground-water velocity gradient to determine the groundwater recharge rate. The method is limited in spatial resolution because deeper water represents water recharged at increasingly greater distances upgradient from the well site.

Tritium concentrations in groundwater samples were determined using the enriched tritium technique at the Environmental Isotope Laboratory, University of Waterloo, Waterloo, Ontario, Canada. Concentrations of dissolved gases and CFCs in groundwater samples were analyzed at the USGS CFC Laboratory in Reston, Virginia, and the ground-water ages estimated using procedures described by Busenburg and Plummer (1992). 


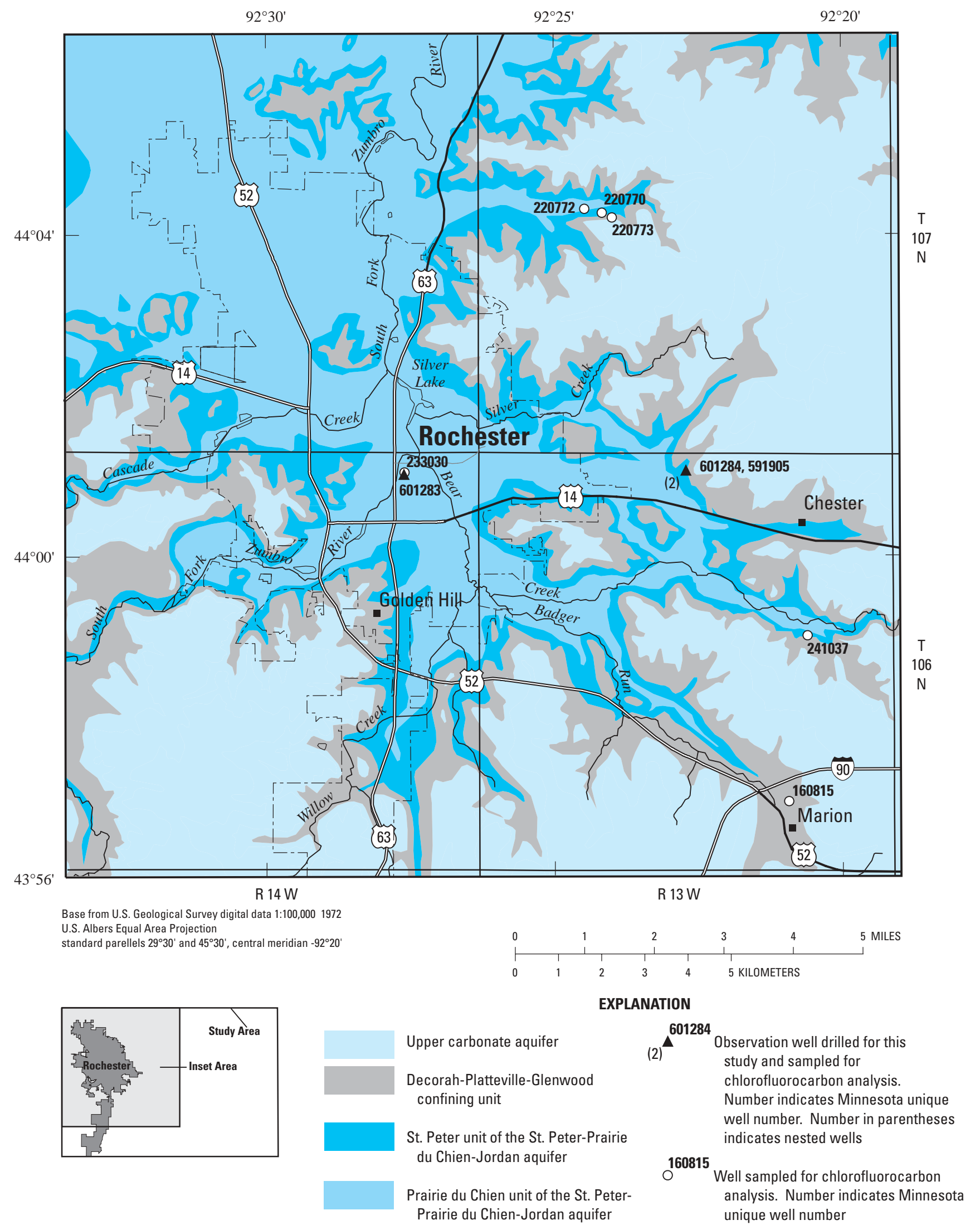

Figure 5. Bedrock hydrogeology and locations of wells sampled for chlorofluorocarbon analysis, Rochester area, Minnesota. 


\section{Modeling of Ground-Water Flow}

A numerical cross-sectional ground-water-flow model of the aquifer system in the Rochester area, hereinafter termed the cross-sectional model, was constructed to test concepts of increased areal recharge and to evaluate ground-water flowpaths near the edge of the Decorah-Platteville-Glenwood confining unit. Water-level measurements for the flowpath wells were used to determine a trace of section for the cross-sectional model and to verify that the direction of horizontal ground-water flow along the flowpath is predominantly east-to-west with no appreciable components of flow in other directions. The influence of tributary valleys on flow within the flowpath was also evaluated. Tributary valleys are distant enough to minimize the effects of horizontal components of lateral flow near the valleys not aligned with the regional east-to-west flowpath.

The cross-sectional model used was the USGS modular three-dimensional, finite-difference ground-waterflow model developed by McDonald and Harbaugh (1988) (MODFLOW). The cross-sectional model was calibrated for steady-state conditions using (1) water levels measured during October and November 1998 in 22 observation wells, and (2) streamflow measurements made on Bear Creek at two sites during November 1998. Estimates of stream-aquifer leakage derived from the streamflow measurements were compared to simulated values. Visual MODFLOW (Guiguer and Franz, 1994) was used as a preprocessor to input the required data, to run the MODFLOW simulations, and as a post-processor to visualize and analyze the results of the simulations.

The particle-tracking post-processing package MODPATH (Pollock, 1989) was used to compute groundwater flowpath lines based on output from the calibrated steady-state simu- lation obtained with MODFLOW. MODPATH also computes the position of particles at specified points in time and the total time of travel for each particle. The particle-tracking program was used by specifying starting locations for hypothetical water particles and then tracking the particles forward in time through the flow field until they reached a sink. The sinks simulated in the cross-sectional model were rivers, drains, and a simulated pumped well. All water particles entering a cell containing a river, drain, or a simulated pumped well were assumed to discharge to these sinks. The particle-tracking program was also used to track water particles backward in time until they reached an inflow boundary. Travel times of water particles from the inflow boundaries of the simulated aquifer system to the sinks where they discharged were also computed using MODPATH.

\section{ACKNOWLEDGMENTS}

The author is grateful to Rochester Public Utilities for performing waterlevel measurements for this study and to Tony Runkel of the Minnesota Geological Survey for providing information on the hydrogeology of the aquifer system in the Rochester area. The author is also grateful to land owners who allowed the installation of observation wells on their property and to well owners who permitted measurement of water levels in their wells. Thanks also are given to employees of the U.S. Geological Survey for their assistance with this study, particularly Michael Menheer, Abdul Mohammad, Robert Borgstede, and Christopher Sanocki.

\section{HYDROGEOLOGIC SETTING}

The sequence of sedimentary rocks in the Rochester area (fig. 2) has been divided into hydrogeologic units of regional aquifers and regional confining units (Delin and Woodward, 1984; Balaban, 1988). Regional bedrock aquifers discussed in this report, in descending order, are the upper carbonate aquifer and the St. Peter-Prairie du Chien-Jordan aquifer (fig. 2). Glacial deposits in the Rochester area locally confine the underlying bedrock aquifers. The reader is referred to Balaban (1988), Delin (1990), and Runkel (1994a, 1994b, and 1996) for a detailed description of the lithology and hydraulic characteristics of the hydrogeologic units in the Rochester area.

\section{HYDROGEOLOGIC UNITS}

The hydrogeologic units in the Rochester area of importance for this report are discussed below in descending order from land surface. Glacial drift overlying bedrock is as much as $100 \mathrm{ft}$ thick in the Rochester area, and locally is thin or absent (Balaban, 1988). Glacial drift includes till and outwash. Till, an unsorted, unstratified sediment deposited directly by glacial ice, contains a high percentage of clay and silt. Outwash is sorted and stratified sand and gravel deposited by water from melting glacier ice. For simplification, post-glacial alluvium composed of silt, sand, and gravel is included with the glacial drift. Sand and gravel lenses in glacial till and the terrace deposits along streams are a source of water for domestic use.

The upper carbonate aquifer is composed of the Galena Group, and is as much as 210-ft thick (Balaban, 1988). The aquifer underlies areas west, south, and east of Rochester (fig. 1). For most of the study area, the Galena Group includes only the Prosser Limestone and the Cummingsville Formation (fig. 2). The Prosser is a very fine-grained, thinbedded limestone that becomes dolomitic near the top. The Cummingsville is a very fine-grained limestone and interbedded calcareous shale, with the shale content decreasing upward, and is less permeable than the overlying Prosser. A third member of the Galena Group, the Stewartville, is present in 
the southern part of the study area. The Stewartville is a fine-grained dolomite and dolomitic limestone. The upper carbonate aquifer supplies water to domestic and farm wells, but is not used for high-capacity wells.

The Decorah-Platteville-Glenwood confining unit hydraulically separates the upper carbonate aquifer from the underlying St. Peter-Prairie du Chien-Jordan aquifer. The confining unit underlies areas west, south, and east of Rochester (fig. 1), with an average thickness of about $70 \mathrm{ft}$ (Balaban, 1988). The Decorah, a blocky, bluish-green to bluish-gray shale, has a very low hydraulic conductivity and is the principal confining unit. The Platteville is a gray to buff, thin-tomedium bedded dolomitic limestone and dolomite with some shale partings. The Glenwood, a plastic to slightly fissile, green to buff shale and claystone, has a low hydraulic conductivity and is a confining unit, and is 5 to $10 \mathrm{ft}$ thick in the Rochester area (Balaban, 1988). Although the Platteville has generally been lumped with the Decorah and Glenwood as a confining unit, it is karsted limestone and will yield some water to wells. Lindgren (1995) simulated the Platteville as a separate aquifer in a numerical cross-sectional groundwater-flow model of the aquifer system in the St. Louis Park area of the Minneapolis-St. Paul metropolitan area, east-central Minnesota (fig. 1).

The St. Peter-Prairie du Chien-Jordan aquifer consists of the St. Peter, Prairie du Chien, and Jordan units (fig. 2). The St. Peter is a fine- to mediumgrained sandstone, well sorted and poorly cemented; its average thickness is approximately $100 \mathrm{ft}$ (Balaban, 1988). The St. Peter underlies areas west, south, and east of Rochester (fig. 1). The Prairie du Chien is composed of the Shakopee Formation, a sandy, shaley, thin-bedded dolomite, and the underlying thick-bedded Oneota Dolomite. Average thickness of the
Prairie du Chien is approximately 300 ft (Balaban, 1988). The Prairie du Chien is generally the uppermost bedrock unit beneath the city of Rochester. The Jordan is a friable to wellcemented, fine- to coarse-grained sandstone with an average thickness of about $100 \mathrm{ft}$ (Balaban, 1988). The Prairie du Chien and Jordan underlie the entire study area.

Hydraulic information indicates that the basal part of the St. Peter impedes the flow of ground water between the St. Peter and the Prairie du Chien units of the aquifer. Measured water-level differences were as much as $7.2 \mathrm{ft}$ (fig. 6) between these two units.

The Prairie du Chien was considered as consisting of two distinct layers for this study. Previous studies in the Rochester area have assumed that the entire Prairie du Chien has more or less uniform hydraulic conductivity and is hydraulically connected to the underlying Jordan. However, recent work conducted in southeastern Minnesota indicates that the lower part of the Prairie du Chien has a reduced hydraulic conductivity compared to the upper part of the Prairie du Chien. Vertical variations in the density of fractures and solution features indicate that the lower part of the Oneota Dolomite within the Prairie du Chien has the lowest density of fractures and solution features, based on video logs and dye tracing (Tony Runkel, Minnesota Geological Survey, written commun., 1999).

The St. Lawrence Formation is a confining unit and is composed of dolomitic siltstone. The confining unit is about $75 \mathrm{ft}$ thick (Balaban, 1988). It is present throughout the study area and immediately underlies the St. Peter-Prairie du Chien-Jordan aquifer.

HYDRAULIC PROPERTIES

Hydraulic-conductivity data are sparse for the aquifers and confining units, other than for the units of the St. Peter-Prairie du Chien-Jordan aquifer.
Data are insufficient to accurately map areal variations in the hydraulic properties of the hydrogeologic units. The hydraulic properties of the aquifer units are discussed first, followed by a discussion of the hydraulic properties of the confining units.

Hydraulic properties of the glacial drift are variable, primarily because of the wide range in composition and sorting of the material. Consequently, glacial drift can be either an aquifer or a confining unit. Where drift consisting mostly of till is relatively thick (greater than $50 \mathrm{ft}$ ), it is a confining unit for the underlying bedrock aquifers. The vertical hydraulic conductivity of till typically ranges from $10^{-6}$ to $1 \mathrm{ft} / \mathrm{d}$ (Freeze and Cherry, 1979, p. 29). Movement of water in the drift is primarily intergranular. Horizontal hydraulic conductivities for glacial aquifers typically range from $10^{1}$ to $10^{4} \mathrm{ft} / \mathrm{d}$ (Freeze and Cherry, 1979, p. 29).

The upper carbonate aquifer yields water primarily to wells that intersect fractures, joints, and solution channels in the carbonate rocks. Transmissivity of the upper carbonate aquifer generally ranges from 300 to $8,400 \mathrm{ft}^{2} / \mathrm{d}$ on the basis of horizontal hydraulic conductivities of 3-40 ft/d (Kanivetsky and Walton, 1979).

Movement of water in the St. Peter unit is primarily intergranular. Transmissivity of the St. Peter ranges from 200 to $3,000 \mathrm{ft}^{2} / \mathrm{d}$, but may be greater than $30,000 \mathrm{ft}^{2} / \mathrm{d}$ locally, based on the results of 58 specific-capacity tests in Olmsted County (Delin, 1990) and on the results of laboratory analyses of rocks from the Minneapolis-St. Paul metropolitan area (Norvitch and others, 1974, p. 114-115).

Transmissivity of the Prairie du Chien unit is highly variable due to secondary permeability caused by fractures and solution cavities. The Prairie du Chien transmits water primarily through fractures, joints, and solution channels. The transmissivity 

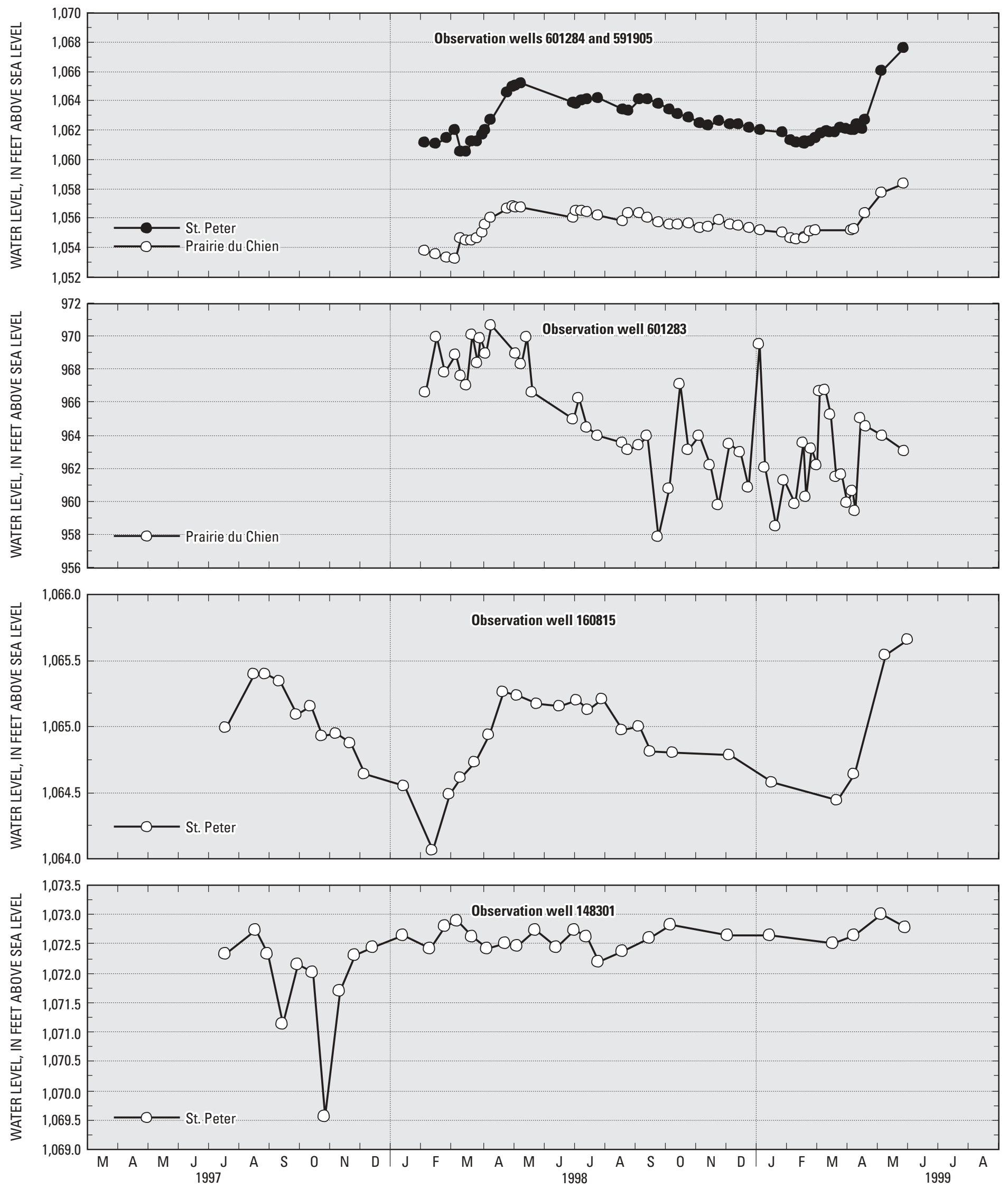

Figure 6. Water levels in observation wells during 1997-99 in the St. 

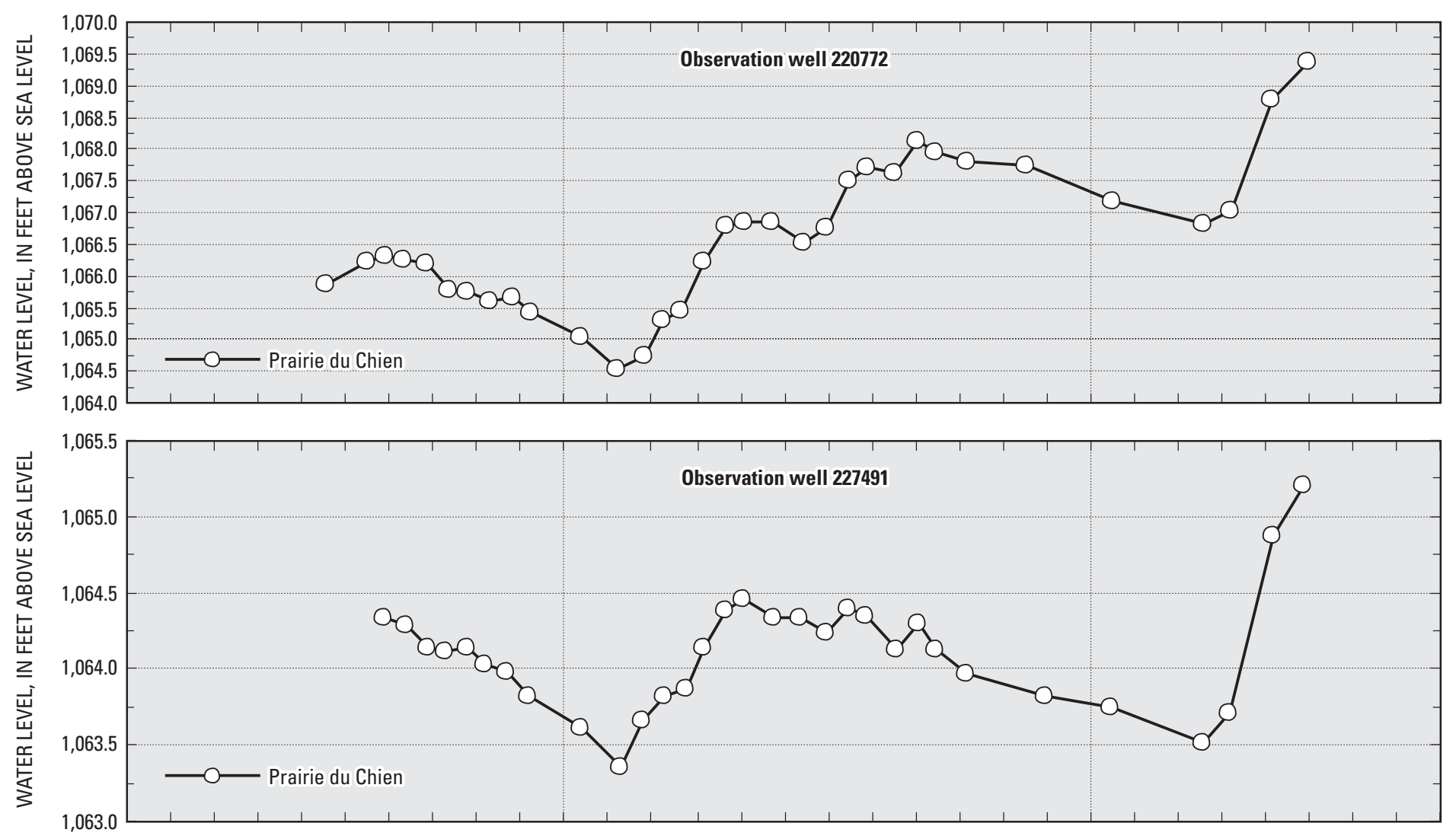

出
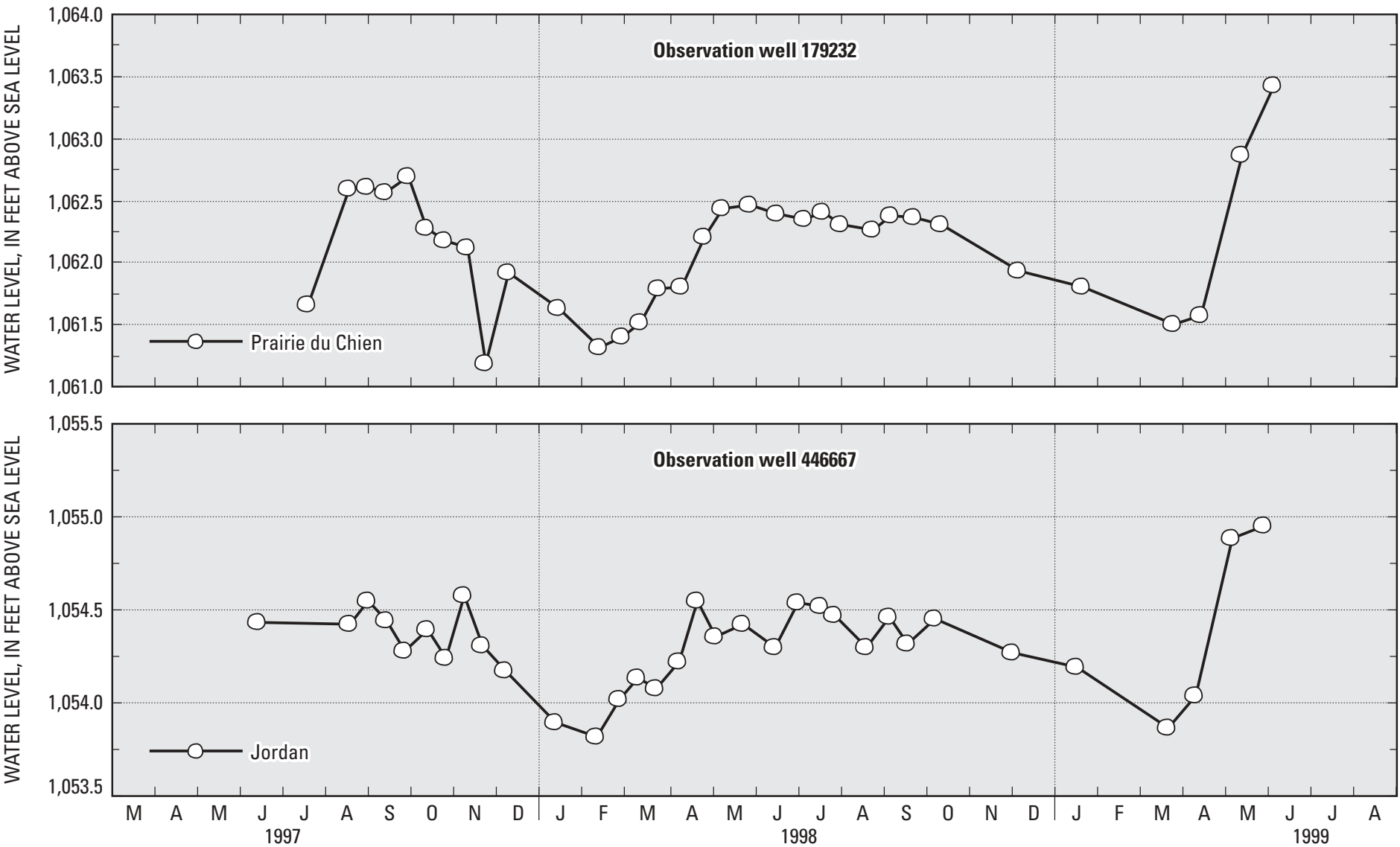

Peter-Prairie du Chien-Jordan aquifer, Rochester area, Minnesota. 
of the Prairie du Chien is from 300 to $1,000 \mathrm{ft}^{2} / \mathrm{d}$ (Delin, 1990). Transmissivities greater than $100,000 \mathrm{ft}^{2} / \mathrm{d}$ were calculated at some wells. Norvitch and others (1974) reported a maximum horizontal hydraulic conductivity of approximately $50 \mathrm{ft} / \mathrm{d}$ for the Prairie du Chien. There is a range in horizontal hydraulic conductivity of at least three orders of magnitude in the upper part of the Prairie du Chien, from as low as $0.85 \mathrm{ft} / \mathrm{d}$ to as high as $8,500 \mathrm{ft} / \mathrm{d}$, based on recent testing of discrete intervals in southeastern Minnesota (Tony Runkel, Minnesota Geological Survey, written commun., 1999). The greatest values of hydraulic conductivity are for wells that intersected well-connected fractures. The lowest values are for wells in comparatively less-fractured parts of the Prairie du Chien. The horizontal hydraulic conductivity of the lower part of the Prairie du Chien may be substantially less than $0.85 \mathrm{ft} / \mathrm{d}$, based on video logs that show thick unfractured intervals of the Oneota Dolomite that have no intergranular permeability (Tony Runkel, Minnesota Geological Survey, written commun., 1999). However, hydraulic tests are unavailable to substantiate this hypothesis.

Movement of water in the Jordan unit is predominantly intergranular. Based on the results of aquifer tests at four municipal wells in Rochester, transmissivity of the Jordan ranged from 100 to $1,700 \mathrm{ft}^{2} / \mathrm{d}$ (Delin, 1990). Transmissivities ranging from 100 to $5,000 \mathrm{ft}^{2} / \mathrm{d}$ were calculated from 54 specific-capacity tests in Olmsted County (Delin, 1990).

Results of aquifer tests for seven Rochester municipal wells open to both the Prairie du Chien and Jordan units of the aquifer indicated that transmissivities were less than 10,000 $\mathrm{ft}^{2} / \mathrm{d}$ for much of the aquifer underlying the central part of the city of Rochester (Lindgren, 1997). Results of aquifer tests for four of the seven wells indicated transmissivities less than
$5,000 \mathrm{ft}^{2} / \mathrm{d}$. The horizontal hydraulic conductivity for each unit of the aquifer ranges from 1 to $35 \mathrm{ft} / \mathrm{d}$ (Delin, 1990). The best-fit calibrated value for vertical hydraulic conductivity was 1 $\mathrm{ft} / \mathrm{d}$ for each unit. Freeze and Cherry (1979) indicate a range in porosity of 0 to 20 percent for limestone and dolomite and 5 to 30 percent for sandstone. In the Rochester area, Delin and Almendinger (1991) reported porosities of 10 percent for the Prairie du Chien and 25 percent for the St. Peter and Jordan, based on published data by Norvitch and others (1974).

A vertical hydraulic conductivity of $10^{-4} \mathrm{ft} / \mathrm{d}$ was estimated for the Decorah-Platteville-Glenwood confining unit from numerical ground-waterflow model analysis in the Minneapolis-St. Paul metropolitan area (Schoenberg, 1990). Delin (1990) reported a value of $10^{-5} \mathrm{ft} / \mathrm{d}$ in the Rochester area, based on Darcy's Law calculations. Specific capacities of wells screened in the Platteville unit of the confining unit in the St. Louis Park area, Minnesota generally are between 10 and $100 \mathrm{gal} / \mathrm{min}$ per foot of drawdown (Stark and Hult, 1985). Results from one aquifer test indicate the transmissivity of the Platteville in the St. Louis Park area is about $9,000 \mathrm{ft}^{2} / \mathrm{d}$ (Stark and Hult, 1985). Rocks with secondary solution cavity and fracture permeability, such as the Platteville, often have heterogeneous hydraulic properties. Liesch (1973) documented large local differences in the transmissivity and storage coefficient of the Platteville in Minneapolis, Minnesota. The vertical hydraulic conductivity of the Glenwood unit of the confining unit was estimated to be $9 \times 10^{-6} \mathrm{ft} / \mathrm{d}$ in the St. Louis Park area, Minnesota, based on laboratory measurements of core samples (Hult and Schoenberg, 1984).

Stark and Hult (1985) reported a vertical hydraulic conductivity of $9 \mathrm{x}$ $10^{-4} \mathrm{ft} / \mathrm{d}$ for the basal St. Peter confining bed in the St. Louis Park area.
Norvitch and others (1974) reported vertical hydraulic conductivities as low as $10^{-6} \mathrm{ft} / \mathrm{d}$ for the basal St. Peter confining bed and Lindgren (1990) reported a value of $1.5 \times 10^{-3} \mathrm{ft} / \mathrm{d}$, based on numerical ground-waterflow model analysis, in the Minneapolis-St. Paul metropolitan area.

Packer-test data in the St. Paul area reported by Miller (1984) indicated a vertical hydraulic conductivity of $10^{-3}$ $\mathrm{ft} / \mathrm{d}$ for the St. Lawrence confining unit, whereas a value of $10^{-5} \mathrm{ft} / \mathrm{d}$ was estimated from numerical groundwater-flow model analysis for the Minneapolis-St. Paul metropolitan area (Schoenberg, 1990). Freeze and Cherry (1979) indicate a range in porosity of from less than 20 to less than 5 percent for shale.

\section{GROUND-WATER RECHARGE}

Ground-water recharge occurs primarily by infiltration of precipitation to the saturated zone (areal recharge). Recharge as used in this report also includes water that leaks downward through the confining units to underlying aquifers. Recharge to the uppermost bedrock unit occurs through a thin (generally less than 50-ft thick) layer of glacial drift.

Hydrograph analysis was used to estimate ground-water recharge rates to the St. Peter-Prairie du Chien-Jordan aquifer for 42 wells. The wells were located in the following hydrogeologic settings: (1a) along the edge of the Decorah-Platteville-Glenwood confining unit on slopes of the South Fork Zumbro River Valley, (1b) along the edge of the confining unit on side slopes of tributary valleys to the South Fork Zumbro River, (1c) along the edge of the confining unit near the head of a tributary valley in the Marion area, (2) where the Decorah-Platteville-Glenwood confining unit is thick and overlain by the upper carbonate aquifer, and (3) in the city of Rochester where the Prairie du Chien is the uppermost bedrock unit. Recharge decreased with depth of well 
completion beneath each of these hydrogeologic settings and ranged from 1.9 to 25.5 in. during all of 1998 (table 1). Recharge was greatest near the edge of the confining unit, with means of as great as $13.8 \mathrm{in}$./yr, similar to results of Delin (1990) who reported a rate of $13 \mathrm{in} . / \mathrm{yr}$ along the edge based on model analyses. The maximum recharge rate of $25.5 \mathrm{in} . / \mathrm{yr}$ was for a St. Peter well (601284, table 2) located downslope from the edge of the confining unit and on the slope of the South Fork Zumbro River Valley. Recharge was least (2.0 in./yr) where the confining unit is thick and overlain by the upper carbonate aquifer. Mean recharge where the Prairie $\mathrm{du}$ Chien is the uppermost bedrock unit ranged from 4.8 to 6.2 in./yr during all of 1998 (table 1), similar to the value of $5 \mathrm{in} . / \mathrm{yr}$ reported by Delin (1990).

Ground-water age dating based on CFC concentrations was used at nine wells to estimate recharge rates to the St. Peter-Prairie du Chien-Jordan aquifer (fig. 5). Recharge rates ranged from 3.0 to 9.7 in./yr in most hydrogeologic settings (table 2). Recharge was greatest (35.3 in./yr) for the St. Peter well (601284) mentioned in the previous paragraph. Recharge dates ranged from: (1) the mid-1950's to the early 1990's for wells in the St. Peter unit, (2) the late 1960's to approximately 1990 for wells in the Prairie du Chien, and (3) the early to mid-1950's for wells in the Jordan.

\section{Water-Level Fluctuations}

Ground-water levels in the Rochester area during 1997-99 fluctuated seasonally in response to variations in recharge and discharge from the aquifer system (fig. 6). Spring peaks in ground-water levels occurred during April 1998 and May 1999 because of snowmelt, spring rain, and minimal evapotranspiration losses (fig. 6). At the time of the last water-level measurements during May 1999, water levels were still rising in most wells, but were likely near spring peak levels. Ground-water levels generally decline in summer due to evapotranspiration, ground-water discharge to streams, and ground-water withdrawals. However, a rise in water levels occurred during July 1998 due to a major storm that resulted in net recharge to the aquifer. Similarly, net recharge also occurred in September 1998 due to rainfall and low evapotranspiration rates.

Hydrographs for the nested observation wells (601284 and 591905) located down slope from the DecorahPlatteville-Glenwood confining unit indicate that water-level fluctuations in the Prairie du Chien and St. Peter units are similar (fig. 6). Fluctuations in the St. Peter were generally of lesser magnitude where the confining unit is thick (well 148301), due to reduced leakage. The comparatively large fluctuations observed in well 148301 during 1997 were due to pumpage. The largest fluctuations in water levels were observed in Prairie du Chien well 601283 because it is within about $1,000 \mathrm{ft}$ of three high-capacity industrial supply wells.

\section{STREAM-AQUIFER LEAKAGE}

Ground-water leakage to streams in the Rochester area generally is greater than leakage from streams to the underlying aquifer, and the streams are therefore gaining streams overall. A gain in streamflow of $0.5 \mathrm{ft}^{3} / \mathrm{s}$ was measured for Bear Creek from US Highway 14 to near its confluence with the South Fork Zumbro River, a distance of approximately one river mile. However, the measured gain in streamflow was approximately 1.3 percent of the flow in the stream $\left(38 \mathrm{ft}^{3} / \mathrm{s}\right)$, less than the assumed accuracy of plus or minus 5 percent for current-meter measurements.

Delin (1990) reported that streamflow increased in about three-fourths of the stream reaches measured for the South Fork Zumbro River, Bear Creek, and Cascade Creek during two synoptic measurement periods during March and August 1987. Estimated stream-aquifer leakage rates were generally less than $5 \mathrm{ft}^{3} / \mathrm{s} / \mathrm{mi}$ (cubic feet per second per stream mile) during the two measurement periods.

The South Fork Zumbro River and Bear Creek flow on top of the Prairie du Chien unit of the St. Peter-Prairie du Chien-Jordan aquifer near the western end of hydrogeologic section A-A' (fig. 4; trace of section shown on figure 3). Streamflow in a reach of the South Fork Zumbro River immediately north of US Highway 14 and adjacent to the western end of hydrogeologic section A-A' decreased during August 1987 by approximately $1 \mathrm{ft}^{3} / \mathrm{s} / \mathrm{mi}$ (Delin, 1990). The measured decrease occurred in a reach near the center of the cone of depression in the potentiometric surface of the St. Peter-Prairie du Chien-Jordan aquifer in Rochester caused by pumpage from high-capacity supply wells (Lindgren, 1997, figs. 6 and 9). Three industrial supply wells are located within $500 \mathrm{ft}$ of two observation wells near the western end of hydrogeologic section $\mathrm{A}-\mathrm{A}^{\prime}$ and are also in close proximity to the losing river reach. Water-level measurements in one observation well located near the three industrial supply wells indicated that hydraulic heads in the Prairie du Chien were consistently lower than the stage in the South Fork Zumbro River at a site approximately $1,000 \mathrm{ft}$ from the observation well. The lower hydraulic head in the Prairie du Chien compared to the nearby river stage indicates that movement of stream water into the aquifer was likely.

\section{GROUND-WATER FLOW}

Ground water in the upper carbonate aquifer moves rapidly through solution-widened fractures and caverns. Where the upper carbonate rock is less affected by karst development, ground water moves slowly through much narrower fractures. Balaban (1988, plate 5) mapped a radial distri- 
Table 1. Estimated ground-water recharge rates to the aquifer system based on hydrograph analysis, Rochester area, Minnesota [in., inches; in./yr, inches per year; --, no estimate or one value only; number in parentheses is number of wells with an estimate for the specified time period; confined, where Decorah-Platteville-Glenwood confining unit is thick]

\begin{tabular}{|c|c|c|c|c|c|c|c|}
\hline \multirow[b]{3}{*}{$\begin{array}{l}\text { Hydrogeologic setting, unit of the } \\
\text { St. Peter-Prairie du Chien-Jordan } \\
\text { aquifer [uppermost bedrock unit] }\end{array}$} & \multirow[b]{3}{*}{$\begin{array}{l}\text { Number of } \\
\text { wells }\end{array}$} & \multicolumn{6}{|c|}{ Time period of estimate } \\
\hline & & \multicolumn{2}{|c|}{ Spring 1998} & \multicolumn{2}{|c|}{ All of 1998} & \multicolumn{2}{|c|}{ Spring 1999} \\
\hline & & $\begin{array}{l}\text { Value or range } \\
\text { (in.) }\end{array}$ & Mean (in.) & $\begin{array}{l}\text { Value or range } \\
\text { (in./yr) }\end{array}$ & Mean (in./yr) & $\begin{array}{l}\text { Value or range } \\
\text { (in.) }\end{array}$ & Mean (in.) \\
\hline \multicolumn{8}{|l|}{ Confined } \\
\hline $\begin{array}{l}\text { St. Peter } \\
\quad[\text { [Galena Group] }\end{array}$ & \multicolumn{6}{|c|}{ St. Peter } & 1.9 \\
\hline \multicolumn{8}{|l|}{ Prairie du Chien } \\
\hline [Galena Group] & 3 & $1.7-2.4$ & 2.1 & -- & -- & $1.0-1.0(2)$ & $1.0(2)$ \\
\hline \multicolumn{8}{|l|}{ Jordan } \\
\hline [Galena Group] & 1 & 1.2 & -- & -- & -- & 1.3 & -- \\
\hline Mean for hydrogeologic setting & & $2.0(6)$ & & & -- & $1.4(5)$ & \\
\hline \multicolumn{8}{|l|}{ Edge (slope of main valley) } \\
\hline \multicolumn{8}{|l|}{ St. Peter } \\
\hline [Platteville Formation] & 1 & 16.8 & -- & 25.5 & -- & 22.5 & -- \\
\hline [Decorah Shale] & 1 & 6.2 & -- & 7.8 & -- & 10.7 & -- \\
\hline \multicolumn{8}{|l|}{ Prairie du Chien } \\
\hline [Platteville Formation] & 3 & $3.2-5.5$ & 4.1 & 8.0 & -- & $3.6-5.3$ & 4.3 \\
\hline Jordan & 0 & -- & -- & -- & -- & -- & -- \\
\hline Mean for hydrogeologic setting & & $7.0(5)$ & & $13.8(3)$ & & $9.2(5)$ & \\
\hline \multicolumn{8}{|c|}{ Edge (side slope of tributary valley) } \\
\hline \multicolumn{8}{|l|}{ Prairie du Chien } \\
\hline [Prairie du Chien Group] & 4 & $2.8-4.1$ & 3.5 & $3.8-9.5$ & 6.2 & $3.2-4.0$ & 3.6 \\
\hline [St. Peter Sandstone] & 4 & $2.1-2.7(3)$ & $2.4(3)$ & $2.6-3.2(3)$ & $2.9(3)$ & $2.1-2.9(3)$ & $2.4(3)$ \\
\hline [Platteville Formation] & 3 & $2.3-3.9$ & 2.8 & $2.6-4.7$ & 3.3 & $2.7-4.2$ & 3.3 \\
\hline [Decorah Shale] & 2 & $3.3-3.6$ & 3.4 & $6.4(1)$ & -- & $3.0-5.8$ & 4.4 \\
\hline \multicolumn{8}{|l|}{ Jordan } \\
\hline [Prairie du Chien Group] & 2 & $2.8-3.4$ & 3.1 & $4.3-5.2$ & 4.8 & $2.6-4.0$ & 3.3 \\
\hline [Galena Group] & 1 & 2.0 & -- & 2.8 & -- & 2.2 & -- \\
\hline [Decorah Shale] & 2 & 1.2 & -- & $1.9(1)$ & -- & $1.3-1.6$ & 1.4 \\
\hline [Platteville Formation] & 1 & 4.1 & -- & 4.8 & -- & 2.6 & -- \\
\hline \multicolumn{8}{|l|}{ Edge (head of tributary valley) } \\
\hline \multicolumn{8}{|l|}{ St. Peter } \\
\hline [Decorah Shale] & 1 & 5.4 & -- & -- & -- & 3.3 & -- \\
\hline [Platteville Formation] & 3 & $4.8-9.3$ & 6.5 & $5.9-10.1$ & 7.4 & $4.4-5.8$ & 5.1 \\
\hline \multicolumn{8}{|l|}{ Prairie du Chien } \\
\hline [Platteville Formation] & 1 & 2.2 & -- & 2.4 & -- & 1.6 & -- \\
\hline Mean for hydrogeologic setting & & $5.4(5)$ & & $6.2(4)$ & & $4.0(5)$ & \\
\hline \multicolumn{8}{|l|}{ Absent } \\
\hline Glacial drift & 3 & $5.3-10.4$ & 8.6 & 19.0 & -- & $4.8-16.8$ & 10.7 \\
\hline \multicolumn{8}{|l|}{ Prairie du Chien } \\
\hline [Prairie du Chien Group] & 4 & $1.1-5.8$ & 3.4 & $2.6-9.6(4)$ & $5.9(4)$ & $1.8-7.0$ & 4.4 \\
\hline Mean for hydrogeologic setting & & $5.4(8)$ & & $8.5(5)$ & & $6.8(8)$ & \\
\hline
\end{tabular}


Table 2. Comparison of ground-water recharge rates to the aquifer system derived from hydrograph analysis, chlorofluorocarbon agedating, and numerical ground-water-flow model analysis, Rochester area, Minnesota

[in., inches; in./yr, inches per year; --no estimate; edge, near edge of confining unit; absent, where confining unit is absent and Prairie du Chien Group is uppermost bedrock unit; CFC, chlorofluorocarbon]

\begin{tabular}{|c|c|c|c|c|c|}
\hline \multirow[b]{3}{*}{$\begin{array}{l}\text { Hydrogeologic setting, unit of the St. Peter-Prai- } \\
\text { rie du Chien-Jordan aquifer, uppermost bedrock } \\
\text { unit [in brackets], and Minnesota unique well } \\
\text { number }\end{array}$} & \multicolumn{3}{|c|}{ Hydrograph analysis } & \multirow{3}{*}{$\begin{array}{l}\mathrm{CFC} \\
\text { analysis } \\
\text { (in./yr) }\end{array}$} & \multirow{3}{*}{$\begin{array}{c}\text { Numerical } \\
\text { model } \\
\text { analysis } \\
\text { (in./yr) }\end{array}$} \\
\hline & \multicolumn{3}{|c|}{ Time period of estimate } & & \\
\hline & $\begin{array}{l}\text { Spring } 1998 \\
\text { Mean } \\
\text { (in.) }\end{array}$ & $\begin{array}{l}\text { All of } 1998 \\
\text { Mean } \\
\text { (in./yr) }\end{array}$ & $\begin{array}{l}\text { Spring } 1999 \\
\text { Mean } \\
\text { (in.) }\end{array}$ & & \\
\hline
\end{tabular}

Edge (Slope of main valley)

St. Peter

[Platteville Formation]

16.8

22.5

Prairie du Chien

[Platteville Formation]

591905

Edge (side slope of tributary valley)

Prairie du Chien

[Prairie du Chien Group]

220770

220772

241037

[Decorah Shale]

220773

Edge (head of tributary)

St. Peter

[Platteville Formation]

160815

Absent

Prairie du Chien

[Prairie du Chien Group]

601283

Prairie du Chien-Jordan

[Prairie du Chien Group]

bution pattern of potentiometric contours from the centers of the large remnants of the upper carbonate aquifer in Olmsted County. This pattern is evident in hydrogeologic section $\mathrm{A}-\mathrm{A}^{\prime}$ (fig. 4), with flow outward from a high in the potentiometric surface of the upper carbonate aquifer located near the center of R12W toward the South Fork Zumbro River Valley to the west and toward the Middle Fork Whitewa- ter River Valley to the east. Discharge into local stream drainages also occurs where the streams have cut into the aquifer, and local stream valleys are the main influence on the volume of water in the aquifer (Balaban, 1988). Many springs occur where the base of the aquifer is exposed or is near the land surface, due to the underlying low-permeability Decorah-PlattevilleGlenwood confining unit that greatly impedes the downward movement of water.

Hydraulic heads in the upper carbonate aquifer are approximately $200 \mathrm{ft}$ higher than in the St. Peter-Prairie du Chien-Jordan aquifer (fig. 4). The difference in heads decreases near the South Fork Zumbro and Middle Fork Whitewater River Valleys due to discharge of water from the upper carbonate aquifer into the river valleys. 
The large vertical gradients indicate that water from the upper carbonate aquifer moves vertically downward through joints or other pathways in the Decorah-Platteville-Glenwood confining unit to the St. Peter-Prairie du Chien-Jordan aquifer. The amount of this vertical leakage, and the areas where it is most likely to occur, are not known. Improper well construction also may add to interaquifer connection.

Horizontal and vertical directions of flow in the aquifer system may be illustrated using hydrogeologic sections and equipotential lines (fig. 4). Figure 4 illustrates predominantly horizontal flow in the upper carbonate and St. Peter-Prairie du Chien-Jordan aquifers and predominantly vertical flow through the Decorah-PlattevilleGlenwood confining unit separating the aquifers. The hydraulic conductivity of the Platteville is appreciably greater than the Decorah and Glenwood, but because it is relatively thin and is bounded by the two confining units it likely has limited affect on flow through the Decorah-PlattevilleGlenwood confining unit. No data are available for hydraulic heads in the Platteville in the Rochester area. The comparatively small variations in hydraulic head vertically within the aquifer units reflect the predominantly horizontal flow in the aquifers (fig. 4). An exception to this generalization within the St. Peter-Prairie du ChienJordan aquifer occurs in the vicinity of the pair of nested observation wells installed for this study in T106N, R13W, section 3, where the measured hydraulic head difference between the St. Peter and Prairie du Chien units is $7.2 \mathrm{ft}$ (fig. 4). The difference in hydraulic heads is partially due to increased ground-water recharge to the St. Peter near the edge of the Decorah unit of the Decorah-PlattevilleGlenwood confining unit, creating a mounding effect and altering the equipotential lines (fig. 4). A further cause may be the localized presence of the basal St. Peter confining bed, although it is not recorded in water-well logs in the Rochester area. Localized confining units within the St. Peter-Prairie du Chien-Jordan aquifer can produce large vertical hydraulic gradients (Delin, 1990).

Regional flow in the St. Peter-Prairie du Chien-Jordan aquifer generally is from a ground-water divide in the potentiometric surface, west, south, and east of Rochester, toward the South Fork Zumbro River (fig. 3). The divide bisects highs in the potentiometric surface, separating groundwater flow toward and away from Rochester. The ground-water divide moves in response to seasonal fluctuations in recharge to and discharge from the aquifer system. Lindgren (1997) reported that there were no appreciable changes in the location of the ground-water divide, however, from 1988 to 1995 . The regional hydraulic gradient is approximately 3 to $20 \mathrm{ft} / \mathrm{mi}$, and increases near the South Fork Zumbro River. Ground-water discharge from the aquifer is to streams, to supply wells completed in the aquifer, and possibly to underlying units as leakage, based on downward vertical gradients in hydraulic heads between units at some locations. Hydraulic head generally increases with depth near streams in the Rochester area, indicating that the vertical component of flow is upward, as is illustrated in hydrogeologic section A$A^{\prime}$ (fig. 4) east of Bear Creek. The lowering of the potentiometric surface in the aquifer due to pumpage by supply wells results in locally downward flow in the area underlying the South Fork Zumbro River (fig. 4).

\section{SIMULATION OF GROUND- WATER FLOW}

A conceptual model was formulated for the selected flowpath in the Rochester area, from knowledge of the hydrogeologic setting, aquifer charac- teristics, distribution and amount of recharge and discharge, and aquifer boundaries. A numerical model of ground-water flow was constructed based on the conceptual model of the aquifer system.

A cross-sectional ground-waterflow model was constructed and calibrated for steady-state (equilibrium) conditions. No storage terms are included in the steady-state simulations. The cross-sectional model was used to test concepts of increased ground-water recharge near the edge of the Decorah-Platteville-Glenwood confining unit and to evaluate groundwater flowpaths in the aquifer system, particularly near the edge of the confining unit.

\section{NUMERICAL MODEL DESCRIPTION}

The flowpath along the trace of hydrogeologic section A-A' (fig. 3) was chosen as representative of the aquifer system and was used to investigate concepts of ground-water flow using the numerical cross-sectional model. Hydrogeologic section A-A' represents a generalized compilation of hydrogeologic information within a 3-mile-wide flowpath area (fig. 3).

The trace of the section is aligned with a horizontal flowpath in the St. PeterPrairie du Chien-Jordan aquifer from the ground-water divide east of Rochester westward to the South Fork Zumbro River. There are no significant horizontal flows normal to the flowpath along the hydrogeologic section, except at the western end of the flowpath.

In the cross-sectional model, the flowpath is represented by rectangular finite-difference grid cells within which the properties of the hydrogeologic unit represented are assumed to be uniform. The variably-spaced finite-difference grid used to spatially discretize the model area has 3 rows and 135 columns (figs. 7a and 7b). Although three rows are simulated in 
the model, it is cross sectional in nature because the hydraulic properties and flows simulated in each row are identical. The simulated hydraulic heads for a given column are the same for each row, except at the western end of the model (columns 1 and 2), where high-capacity supply wells are simulated. Three rows are included in the model to minimize boundary effects at the western end of the model. Notation of the form $(3,2,120)$, where the first number in parentheses indicates the layer, the second number indicates the row, and the third number represents the column, is used to refer to the location of an individual cell within the grid. The dimensions of the grid cells are $880 \mathrm{ft}$ along rows and range from 100 to $1,000 \mathrm{ft}$ along columns. The smallest cells are near the edge of the Decorah-Platteville-Glenwood confining unit, where the most detail is needed.

The aquifer system along the flowpath was subdivided into 11 layers, corresponding to the generally horizontal hydrogeologic units (fig. 7a, and table 3). The glacial drift was included in the model as layer 1 , but was designated as inactive for the simulations because it is generally thin (less than $50 \mathrm{ft}$ thick) and unsaturated along the simulated flowpath. The lower part of the upper carbonate aquifer has a greater shale content, and presumably a lower hydraulic

conductivity, than the upper part. The individual units of the Decorah-Platteville-Glenwood confining unit and the St. Peter-Prairie du Chien-Jordan aquifer were simulated as separate layers in the cross-sectional model due to the detailed nature of the model and to allow for an investigation of the simulated effects of variations in confining unit and aquifer structure. Layer 8, representing the basal St. Peter confining bed, was not initially included in the model, as discussed later in the Numerical Model Calibration section. Layer 9, representing the upper part of the Prairie du Chien unit of the St. Peter-Prairie du Chien-Jordan aquifer was assigned a greater hydraulic conductivity because it contains a greater density of fractures and solution features than for the lower part (represented by layer 10).

The altitudes of the layer tops and bottoms were specified for each model cell for the 11 model layers. The thickness of a cell representing a hydrogeologic unit is incorporated in the transmissivity term for the cell. The transmissivities of layers 4, 5, 6, 8, 10 , and 11 are constant in time for any individual model cell. The units are under confined conditions so their model-calculated saturated thicknesses do not vary. Layers 2, 3, 7, and 9 are unconfined or confined along different parts of the modeled flowpath. The transmissivities of cells representing these units vary where the units are under unconfined conditions and are constant in time where the units are under confined conditions.

Ideally, all model boundaries should be located at the physical limits of the aquifer system or at other hydrologic boundaries, such as a major river. The lateral boundaries for all layers in the cross-sectional model represent natural no-flow boundaries of the aquifer system. The lateral boundaries for layers 2-6 are located where the hydrogeologic units they represent are fully incised by the South Fork Zumbro River Valley on the west and by the Middle Fork Whitewater River Valley on the east. These units are truncated by the river valleys and there is no ground-water flow across the boundaries, other than from springs and seeps. The western boundaries of layers 7 and 8 are also located where the units are fully incised by the South Fork Zumbro River Valley, with no ground-water flow across the boundaries.

The eastern boundaries of layers 711 are located at the ground-water divide of the St. Peter-Prairie du
Chien-Jordan aquifer located east of Rochester (fig. 3). This ground-water divide represents a plane of highest hydraulic head in the aquifer that generally separates flow westward toward and eastward away from Rochester. The western boundaries of layers 9-11 are located at the South Fork Zumbro River. These boundaries are simulated as no-flow boundaries because the potentiometric contours indicate that the flow direction in that area is predominantly south to north, normal to the line of section.

The effects of the component of flow normal to the line of section at the western end of the simulated flowpath, and the exclusion from the model of this potential source of water due to the use of no-flow boundaries, was evaluated. A simulation was done specifying a constant head with an altitude of $975 \mathrm{ft}$ for layer 9, at the western end of the simulated flowpath (cell 9,3,1) (fig. 3). The constant head allowed water to move into the cell, simulating the potential source of water derived from the indicated south-to-north ground-water flow. The effects of the constant head on hydraulic heads and flows in the simulated aquifer system were minimal. The simulated flow into the constant-head cell was $0.06 \mathrm{ft}^{3} / \mathrm{s}$. The simulated hydraulic head changes were less than $0.1 \mathrm{ft}$, with simulated heads being unchanged in most cells. The simulated leakage from the South Fork Zumbro River to the upper Prairie du Chien was reduced by $0.05 \mathrm{ft}^{3} / \mathrm{s}$, indicating that the primary effect of the source of water from the south not simulated in the cross-sectional model would be to lessen leakage from the South Fork Zumbro River into the upper Prairie du Chien. The leakage from the South Fork Zumbro River into the upper Prairie du Chien is caused by pumpage from a highcapacity well simulated in cell $(11,2,1)$. The small magnitude of the simulated boundary inflow and result- 

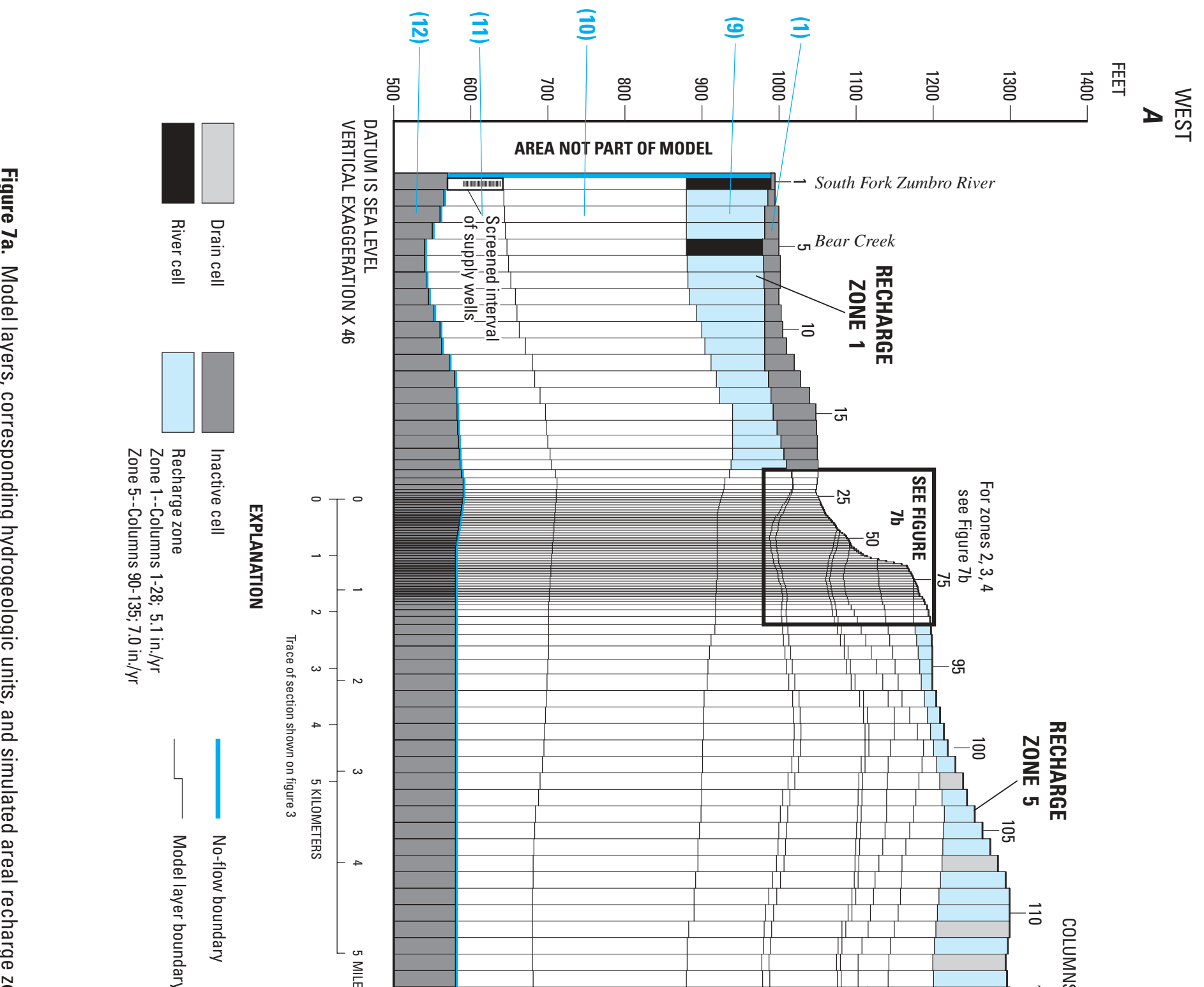

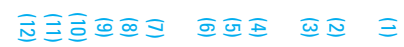
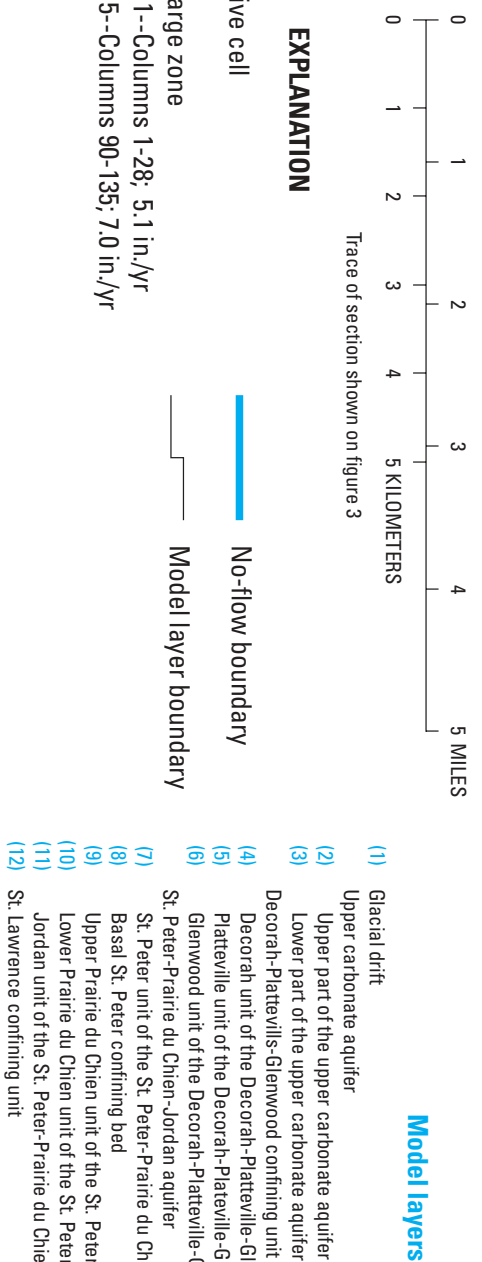

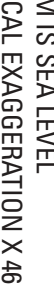
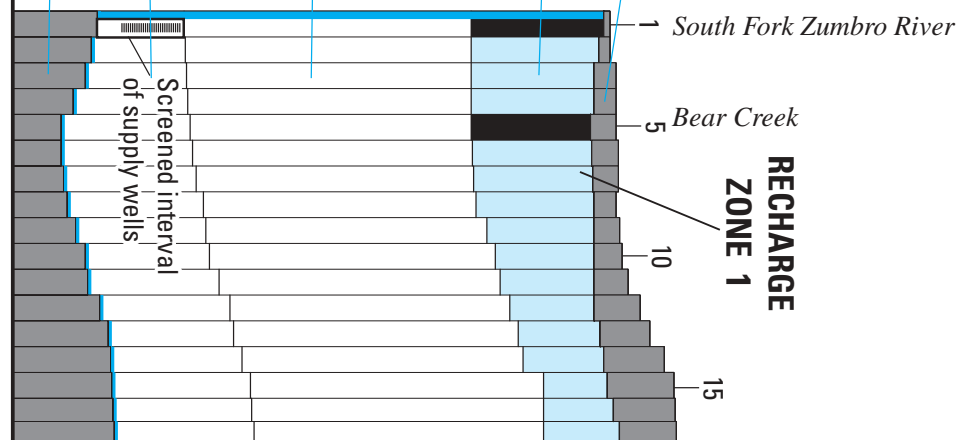


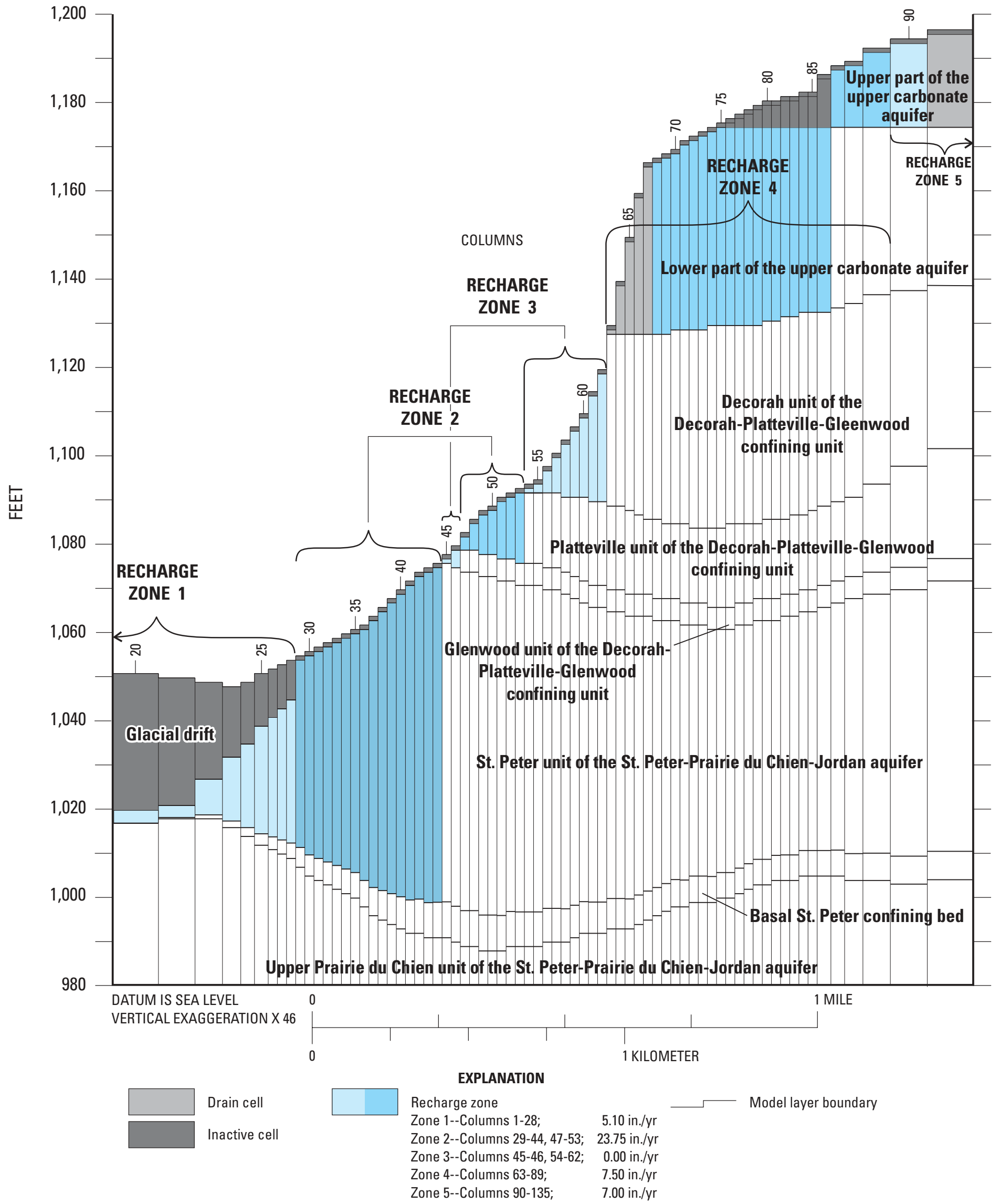

Figure 7b. Model layers, corresponding hydrogeologic units, and simulated areal recharge zones near edge of confining units, Rochester area, Minnesota. 
Table 3. Initial and best-fit calibrated values of hydraulic properties used in the cross-sectional model of the aquifer system, Rochester area, Minnesota

[ft/d, feet per day; NA, model layer is inactive and no hydraulic properties were assigned]

\begin{tabular}{|c|c|c|c|c|c|c|c|}
\hline \multirow[b]{2}{*}{ Hydrogeologic unit } & \multirow[b]{2}{*}{ Model layer } & \multirow[b]{2}{*}{ Model columns } & \multicolumn{2}{|c|}{$\begin{array}{l}\text { Horizontal hydraulic } \\
\text { conductivity (ft/d) }\end{array}$} & \multicolumn{2}{|c|}{$\begin{array}{l}\text { Vertical hydraulic } \\
\text { conductivity (ft/d) }\end{array}$} & \multirow[b]{2}{*}{ Porosity } \\
\hline & & & Initial & Calibrated & Initial & Calibrated & \\
\hline Glacial drift & 1 & Inactive & NA & NA & NA & NA & NA \\
\hline Upper part of the upper carbonate aquifer & 2 & $87-129$ & ${ }^{1} 35$ & 20 & ${ }^{2} 1.0$ & 2.0 & ${ }^{2} 0.10$ \\
\hline Lower part of the upper carbonate aquifer & 3 & $63-134$ & $1_{25}$ & 10 & ${ }^{2} 1.0$ & 1.0 & ${ }^{2} 0.10$ \\
\hline $\begin{array}{l}\text { Decorah unit of the Decorah-Platteville- } \\
\text { Glenwood confining unit }\end{array}$ & 4 & $54-134$ & ${ }^{3} 0.00001$ & 0.00001 & ${ }^{3} 0.00001$ & 0.00001 & ${ }^{4} 0.05$ \\
\hline $\begin{array}{l}\text { Platteville unit of the Decorah-Platteville- } \\
\text { Glenwood confining unit }\end{array}$ & 5 & $47-134$ & ${ }^{2} 35$ & 1.0 & ${ }^{2} 1.0$ & 1.0 & ${ }^{2} 0.10$ \\
\hline $\begin{array}{l}\text { Glenwood unit of the Decorah-Plat- } \\
\text { teville-Glenwood confining unit }\end{array}$ & 6 & $44-134$ & ${ }^{3} 0.00001$ & 0.00001 & ${ }^{3} 0.00001$ & 0.00001 & ${ }^{4} 0.05$ \\
\hline $\begin{array}{l}\text { St. Peter unit of the St. Peter-Prairie du } \\
\text { Chien-Jordan aquifer }\end{array}$ & 7 & $21-135$ & ${ }^{3} 35$ & 25 & ${ }^{3} 1.0$ & 1.0 & $5^{5} 0.25$ \\
\hline Basal St. Peter confining bed & 8 & $21-135$ & ${ }^{6} 0.0015$ & 0.0015 & ${ }^{6} 0.0015$ & 0.0015 & ${ }^{4} 0.05$ \\
\hline $\begin{array}{l}\text { Upper Prairie du Chien unit of the St. } \\
\text { Peter-Prairie du Chien-Jordan aquifer }\end{array}$ & 9 & $1-135$ & ${ }^{3} 35$ & 12.5 & ${ }^{3} 1.0$ & 1.0 & ${ }^{5} 0.10$ \\
\hline $\begin{array}{l}\text { Lower Prairie du Chien unit of the St. } \\
\text { Peter-Prairie du Chien-Jordan aquifer }\end{array}$ & 10 & $1-135$ & ${ }^{7} 0.85$ & 0.85 & ${ }^{7} 0.05$ & 0.05 & ${ }^{7} 0.075$ \\
\hline $\begin{array}{l}\text { Jordan unit of the St. Peter-Prairie du } \\
\text { Chien-Jordan aquifer }\end{array}$ & 11 & $1-135$ & ${ }^{3} 35$ & 45 & ${ }^{3} 1.0$ & 1.0 & ${ }^{4} 0.10$ \\
\hline
\end{tabular}

ing change in stream-aquifer leakage, however, indicates that the effects are minimal for the purposes of this steady-state model.

Simulation of leakage of water between model layers is dependent on the thicknesses and vertical hydraulic conductivities between adjacent layers. A more detailed discussion of leakage of water between model layers can be found in McDonald and Harbaugh (1988). Layer 11 is underlain by the St. Lawrence confining unit. The volume vertical flow across the base of layer 11 is small compared to the horizontal flow in the unit, and the base can be treated as a no-flow boundary.

A specified-flux boundary was used to represent areal recharge to the uppermost active layer for each model column. Where a confining unit is the uppermost bedrock unit, no areal recharge was simulated. The crosssectional model was not used to simulate ground-water losses to evapotranspiration because these losses occur in only a small percentage of the flowpath area, primarily in the immediate vicinity of streams, where the water table is less than $5 \mathrm{ft}$ below land surface.

Areal recharge rates were assigned to five zones (figs. $7 \mathrm{a}$ and $7 \mathrm{~b}$; table 4). The initial simulated areal recharge rates for the five zones (table 4) were based on recharge rates reported by Delin (1990) in the Rochester area for zones 1 and 2 and on ranges of areal recharge reported elsewhere in Minnesota for zones 3,4 , and 5 .

Stream-aquifer leakage was simulated with head-dependent flux nodes
(McDonald and Harbaugh, 1988). Stream-aquifer leakage through a reach of streambed is approximated by Darcy's Law as:

$$
\mathrm{Q}_{\mathrm{RIV}}=(\mathrm{KLW} / \mathrm{M})\left(\mathrm{H}_{\mathrm{RIV}} \mathrm{H}_{\mathrm{AQ}}\right) \text {, }
$$
where:

$\mathrm{Q}_{\mathrm{RIV}}=$ stream-aquifer leakage through the reach of the streambed $\left(\mathrm{L}^{3} / \mathrm{T}\right)$,

$\mathrm{K}=$ vertical hydraulic conductivity of the streambed $(\mathrm{L} / \mathrm{T})$,

$\mathrm{L}=$ length of the reach $(\mathrm{L})$,

$\mathrm{W}=$ width of the stream $(\mathrm{L})$,

$\mathrm{M}=$ thickness of the streambed (L),

$\mathrm{H}_{\mathrm{AQ}}=$ head in the aquifer (L), and $\mathrm{H}_{\mathrm{RIV}}=$ head in the stream (L).

The length of the streambed in each river cell was measured from USGS 7.5-minute-quadrangle topographic maps. The average width of the South 
Fork Zumbro River and Bear Creek streambeds, measured at stream discharge measurement sites at the west end of the flowpath, is about $60 \mathrm{ft}$. Average streambed width for the Middle Fork Whitewater River was estimated to be about the same. The thickness of the streambed was assumed to be $1 \mathrm{ft}$ for the model, as for other studies (Yager, 1993; Lindgren, 1990). The lower limit of the streambed is poorly defined and not easily measurable. The initial value used in the cross-sectional model for vertical hydraulic conductivity of the South Fork Zumbro, Bear Creek, and Middle Fork Whitewater streambeds was 0.1 $\mathrm{ft} / \mathrm{d}$, based on values reported by Delin (1990).

Discharge from layer 2 by springs and seeps into local stream drainages occurring where streams have cut into the aquifer was simulated using the drain package of MODFLOW (McDonald and Harbaugh, 1988). Discharge by springs and seeps from layer 3 into the Middle Fork Whitewater River drainage at the eastern end of the simulated flowpath and at the edge of the Decorah unit of the confining unit was also simulated using the drain package. Seven drain cells were simulated in layer 2 and nine drain cells were simulated in layer 3 (figs. $7 \mathrm{a}$ and $7 b)$.

Discharge from the model cell into the drain is calculated as:

$\mathrm{Q}_{\mathrm{D}}=\mathrm{C}_{\mathrm{D}}$ (H-D), where:

$\mathrm{Q}_{\mathrm{D}}=$ discharge to the drain $\left(\mathrm{L}^{3} / \mathrm{T}\right)$,

$\mathrm{C}_{\mathrm{D}}=$ conductance $\left(\mathrm{L}^{2} / \mathrm{T}\right)$,

$\mathrm{H}=$ head in the aquifer (L), and

$\mathrm{D}=$ altitude of the drain (L).

The conductance was assumed to be proportional to the area of the drain and the hydraulic conductivity of the aquifer material. The altitude of the streambed dissecting the aquifer, determined from USGS 7.5-minutequadrangle topographic maps, was specified as the drain altitude. The altitude of the bottom of layer 3 was specified as the altitude of the drain at the edge of the Decorah unit of the confining unit.

Ground water is withdrawn by three high-capacity industrial supply wells located near the South Fork Zumbro River at the western end of the simulated flowpath. A total of 230.6 million gallons of water was pumped from the three wells during 1998 (Harry Root, Associated Milk Producers, Inc., Plant Engineer, written commun., 1999). Two of the supply wells are open to the Jordan unit of the aquifer (layer 11). A third supply well is open to the Jordan and both the upper and lower Prairie du Chien units of the aquifer, but pumped only 0.1 percent of the water withdrawn during 1998. All of the water withdrawn by the supply wells was simulated as being pumped from the Jordan from cell $(11,2,1)$ in the cross-sectional model. The effects of the lateral noflow boundaries on drawdowns due to the simulated pumpage are less than $0.1 \mathrm{ft}$.

The initial and best-fit calibrated values of hydraulic properties represented in the cross-sectional model are listed in table 3 and the values for areal recharge are listed in table 4 . Initial values for horizontal and vertical hydraulic conductivities and porosity for each hydrogeologic unit were based on previous studies in the Roch-

Table 4. Initial and best-fit calibrated values of areal recharge rate used in the cross-sectional model of the aquifer system, Rochester area, Minnesota

[All recharge rates are in inches per year]

\begin{tabular}{|c|c|c|c|c|c|}
\hline \multirow{2}{*}{$\begin{array}{l}\text { Areal recharge } \\
\text { zone }\end{array}$} & \multirow{2}{*}{ Model columns } & \multirow{2}{*}{ Model layer } & \multirow{2}{*}{ Hydrogeologic unit } & \multicolumn{2}{|c|}{ Areal recharge rate } \\
\hline & & & & Initial & Calibrated \\
\hline \multirow[t]{2}{*}{1} & $1-20$ & 9 & $\begin{array}{l}\text { Upper Prairie du Chien unit of the St. Peter-Prairie du Chien- } \\
\text { Jordan aquifer }\end{array}$ & 5.0 & 5.1 \\
\hline & $21-28$ & 7 & St. Peter unit of the St. Peter-Prairie du Chien-Jordan aquifer & & \\
\hline \multirow[t]{2}{*}{2} & $29-44$ & 7 & St. Peter unit of the St. Peter-Prairie du Chien-Jordan aquifer & 13.0 & 23.75 \\
\hline & $47-53$ & 5 & $\begin{array}{l}\text { Platteville unit of the Decorah-Platteville-Glenwood confin- } \\
\text { ing unit }\end{array}$ & & \\
\hline \multirow[t]{2}{*}{3} & $45-46$ & 6 & $\begin{array}{l}\text { Glenwood unit of the Decorah-Platteville-Glenwood confin- } \\
\text { ing unit }\end{array}$ & 0.0 & 0.0 \\
\hline & $54-62$ & 4 & $\begin{array}{l}\text { Decorah unit of the Decorah-Platteville-Glenwood confining } \\
\text { unit }\end{array}$ & & \\
\hline \multirow[t]{2}{*}{4} & $63-86$ & 3 & Lower part of the upper carbonate aquifer & 7.0 & 7.5 \\
\hline & $87-89$ & 2 & Upper part of the upper carbonate aquifer & & \\
\hline \multirow[t]{3}{*}{5} & $90-129$ & 2 & Upper part of the upper carbonate aquifer & 7.0 & 7.0 \\
\hline & $130-134$ & 3 & Lower part of the upper carbonate aquifer & & \\
\hline & 135 & 7 & St. Peter unit of the St. Peter-Prairie du Chien-Jordan aquifer & & \\
\hline
\end{tabular}


ester area, published values for other areas in Minnesota, and unpublished information from previous work in the Rochester area (Tony Runkel, Minnesota Geological Survey, written commun., 1999).

\section{NUMERICAL MODEL CALIBRATION}

Model calibration is the process in which initial estimates of aquifer properties and boundary conditions are adjusted until simulated hydraulic heads and flows acceptably match measured hydraulic heads and flows. For this study, aquifer properties and areal recharge were adjusted to produce an acceptable match between simulated and measured hydraulic heads and stream-aquifer leakage. Model-computed stream-aquifer leakage was compared to leakage between South Fork Zumbro River, Bear Creek, and the upper Prairie du Chien unit of the aquifer based on measured streamflows during November 1998 and during 1987 (Delin, 1990).

Water levels in 22 wells during October and November 1998 and streamflows at 2 sites on Bear Creek during November 1998 were used to calibrate the cross-sectional model under steady-state conditions. A map showing the potentiometric surface of the upper carbonate aquifer was published by Balaban (1988, plate 5). The locations of the $1,250-\mathrm{ft}$ and $1,280-\mathrm{ft}$ contours from that map along the modeled flowpath were also used to calibrate the model. Four hypothetical observation wells were simulated in the model at the locations of these contours and included in the calculations of average differences between simulated and measured hydraulic heads.

The model was calibrated by varying the simulated values of (1) horizontal and vertical hydraulic conductivities of the hydrogeologic units, (2) hydraulic conductivity of the streambeds, and (3) areal recharge to the aquifers. The match between measured and simulated hydraulic heads and stream-aquifer leakage was improved by (1) reducing the horizontal hydraulic conductivities for layers $2,3,5,7$, and 9 , and (2) increasing the horizontal hydraulic conductivity for layer 11 . The best-fit calibrated values are considered reasonable because they are all within previously reported values in the Rochester area and elsewhere in Minnesota. The initial values used for porosity for the hydrogeologic units were not varied because porosity is only used by the post-processing package MODPATH to determine average linear ground-water velocities for use in time-related capture zones and time markers along pathlines. The initial value for streambed hydraulic conductivity was varied by an order of magnitude during the calibration process, but the best-fit calibrated value was the same as the initial value of $0.1 \mathrm{ft} / \mathrm{d}$. The conductance values specified for the drain package of MODFLOW were not varied during the calibration of the model because there were no data available to compare simulated and measured outflow from springs and seeps.

The calibration was also improved by the addition of the basal St. Peter confining bed (layer 8). The confining bed was needed to acceptably simulate measured vertical hydraulic head differences between the aquifer units along the simulated flowpath, which are as much as $7.2 \mathrm{ft}$ near the edge of the Decorah-Platteville-Glenwood confining bed. Without the inclusion of this confining unit, simulated hydraulic head differences between the two aquifer units within a column were approximately $0.5 \mathrm{ft}$ or less.

The best-fit calibrated areal recharge rates were greater than the initial values for three of the five simulated recharge zones (table 4). The increases for two of the three zones are minimal. It is reasonable that the simulated areal recharge rates to the aquifers are at the upper end of the range of values calculated using hydrograph analysis, considering that, at many of the wells included in the hydrographanalysis calculations the aquifer units were overlain by confining units of varying thicknesses. The best-fit calibrated areal recharge rate near the edge of the Decorah-Platteville-Glenwood confining unit, where recharge is greatest, is appreciably greater than the initial value of $13.0 \mathrm{in} . / \mathrm{yr}$ (reported by Delin, 1990). The best-fit calibrated rate of $23.75 \mathrm{in} . / \mathrm{yr}$, however, is in good agreement with the calculated value from hydrograph analysis of $25.5 \mathrm{in} . / \mathrm{yr}$ for a well screened in the St. Peter unit.

The calibrated cross-sectional model acceptably matches measured hydraulic heads, as indicated by the simulated equipotential lines shown in figures $8 \mathrm{a}$ and $8 \mathrm{~b}$. The best-fit calibrated hydraulic heads were within 4.3 $\mathrm{ft}$ of measured water levels at all of the 22 wells used to calibrate the model and within $1.7 \mathrm{ft}$ of water levels in the four hypothetical observation wells based on the potentiometric contours reported by Balaban (1988). The differences between simulated and measured hydraulic heads were $2.0 \mathrm{ft}$ or less in 17 of the 26 observation wells. The mean absolute difference between simulated and measured hydraulic heads is $1.80 \mathrm{ft}$. The mean algebraic difference between simulated and measured hydraulic heads is $+0.04 \mathrm{ft}$, indicating that the positive differences were approximately balanced by the negative differences.

Measured vertical differences in hydraulic heads between aquifer units were also acceptably simulated by the cross-sectional model. The measured difference in hydraulic heads between the St. Peter and upper Prairie du Chien units at a site with nested monitoring wells was $7.2 \mathrm{ft}$. The simulated difference between hydraulic heads in the St. Peter and upper Prairie du Chien at that location was $8.2 \mathrm{ft}$. The nested well site is located in T106N,R13W, section 3 (fig. 3). The 
measured difference in hydraulic heads for a pair of wells located approximately $150 \mathrm{ft}$ apart in T106N,R13W, section 2, a monitoring well installed for this study screened in the upper Prairie du Chien and a domestic well open to the Jordan, was $1.1 \mathrm{ft}$. The simulated difference between hydraulic heads in the upper Prairie du Chien and Jordan near that location was $0.5 \mathrm{ft}$.

The model duplicated the correct direction and approximate amount of stream-aquifer leakage. The measured gain in streamflow during November 1998 for an approximately 1 mile reach of Bear Creek, near the west end of the simulated flowpath, was $0.5 \mathrm{ft}^{3} / \mathrm{s}$, similar to the simulated leakage of water from the upper Prairie du Chien to Bear Creek of $0.64 \mathrm{ft}^{3} / \mathrm{s}$ per river mile. The simulated leakage of water from the South Fork Zumbro River to the upper Prairie du Chien unit was $0.30 \mathrm{ft}^{3} / \mathrm{s}$ per river mile.

A water budget is an accounting of inflow to, outflow from, and storage change in the aquifer system. For steady state, inflow (sources) to the aquifer equals outflow (discharges) from the aquifer (table 5) and storage change is zero. Along the simulated flowpath areal recharge accounts for 93.7 percent of the sources of water to the aquifer system. Leakage from the South Fork Zumbro River to the upper Prairie du Chien unit of the aquifer (layer 9) (4.1 percent) and from the Middle Fork Whitewater River to the St. Peter unit of the aquifer (layer 7) (2.2 percent) are comparatively minor sources of water. Most of the areal recharge enters the aquifer system through the upper carbonate aquifer (layers 2 and 3) (66.5 percent) east of the edge of the Decorah-Platteville-

Glenwood confining unit and through the upper Prairie du Chien unit of the aquifer (layer 9) (19.9 percent) west of the edge of the confining unit. The amount of areal recharge entering the aquifer system near the edge of the Decorah unit (layer 4) through the
Platteville unit (layer 5) (3.3 percent) and St. Peter unit of the aquifers in (layer 7) (9.5 percent) is much less than through the upper carbonate aquifer.

The largest simulated discharge from the aquifer system is outflow through springs and seeps from the upper carbonate aquifer (layers 2 and 3) (61.0 percent). Of the $2.28 \mathrm{ft}^{3} / \mathrm{s}$ of areal recharge that enters the upper carbonate aquifer, $2.23 \mathrm{ft}^{3} / \mathrm{s}$ is discharged from the aquifer by springs and seeps, leaving only $0.05 \mathrm{ft}^{3} / \mathrm{s}(2.2$ percent) to leak downward to the underlying part of the aquifer system. Excluding outflow through springs and seeps, the largest discharge from the aquifer system is by pumpage from the three industrial supply wells (layer 11) simulated in cell $(11,2,1)$, $1.11 \mathrm{ft}^{3} / \mathrm{s}$ (30.3 percent). The sources of water withdrawn by the wells are (1) leakage of water from the South Fork Zumbro and Middle Fork Whitewater Rivers $\left(0.23 \mathrm{ft}^{3} / \mathrm{s}, 20.7\right.$ percent of pumpage), and (2) areal recharge $\left(0.88 \mathrm{ft}^{3} / \mathrm{s}, 79.3\right.$ percent of pumpage $)$ (fig. 9a). Some areal recharge entering the aquifer system through the upper Prairie du Chien, the Platteville, and the St. Peter discharges to Bear Creek $\left(0.32 \mathrm{ft}^{3} / \mathrm{s}, 27.8\right.$ percent of that areal recharge). The small amount of water leaking downward from the upper carbonate aquifer to the underlying aquifer system is withdrawn by the supply wells or discharges to Bear Creek.

Water flows vertically through the confining units in the aquifer system in both upward and downward directions (table 6). Table 6 summarizes simulated vertical leakage between model layers in the aquifer system. Much larger discharges occur through the lower boundary of a hydrogeologic unit (downward flow) than through the upper boundary (upward flow). The largest downward flows are for layers 9 and 10, due to the greater areal extent of their simulated boundaries and the influence of the simulated pumpage in cell $(11,2,1)$.

\section{SENSITIVITY ANALYSIS}

A model-sensitivity analysis, wherein a single hydraulic property or flux is varied while all other properties and fluxes are held constant, was done to identify the relative effect of adjustments of hydraulic properties and fluxes on simulated hydraulic heads and stream-aquifer leakage. The degree to which the properties and fluxes were varied was related to the uncertainty associated with each. Variations were kept within reported or plausible ranges of values.

Simulated hydraulic heads for the cross-sectional steady-state model were most sensitive to variations in areal recharge, horizontal hydraulic conductivity of the Prairie du Chien and Jordan units of the St. Peter-Prairie du Chien-Jordan aquifer, and streambed hydraulic conductivity (table 7). Increases in the areal recharge rate to zone 2 (zone of greatest simulated recharge downslope from the edge of the Decorah unit), and both increases and decreases in the horizontal hydraulic conductivity value for the Jordan unit, resulted in the greatest mean deviations in hydraulic heads. Varying the areal recharge rate to zone 2 resulted in mean deviations similar to those resulting from changing the rates to the other four zones combined, although the land surface area of zone 2 constitutes only about 3.5 percent of the total area. Varying the vertical hydraulic conductivities of the confining units by an order of magnitude had no discernible effect on simulated hydraulic heads in the aquifer system.

The greatest percent changes in stream-aquifer leakage resulted from variations in areal recharge and streambed hydraulic conductivity (table 7). Variations in the horizontal hydraulic conductivity of the Jordan unit also resulted in appreciable changes in stream-aquifer leakage, particularly in leakage from the South Fork Zumbro River to the underlying St. Peter-Prairie du Chien-Jordan aquifer due to 


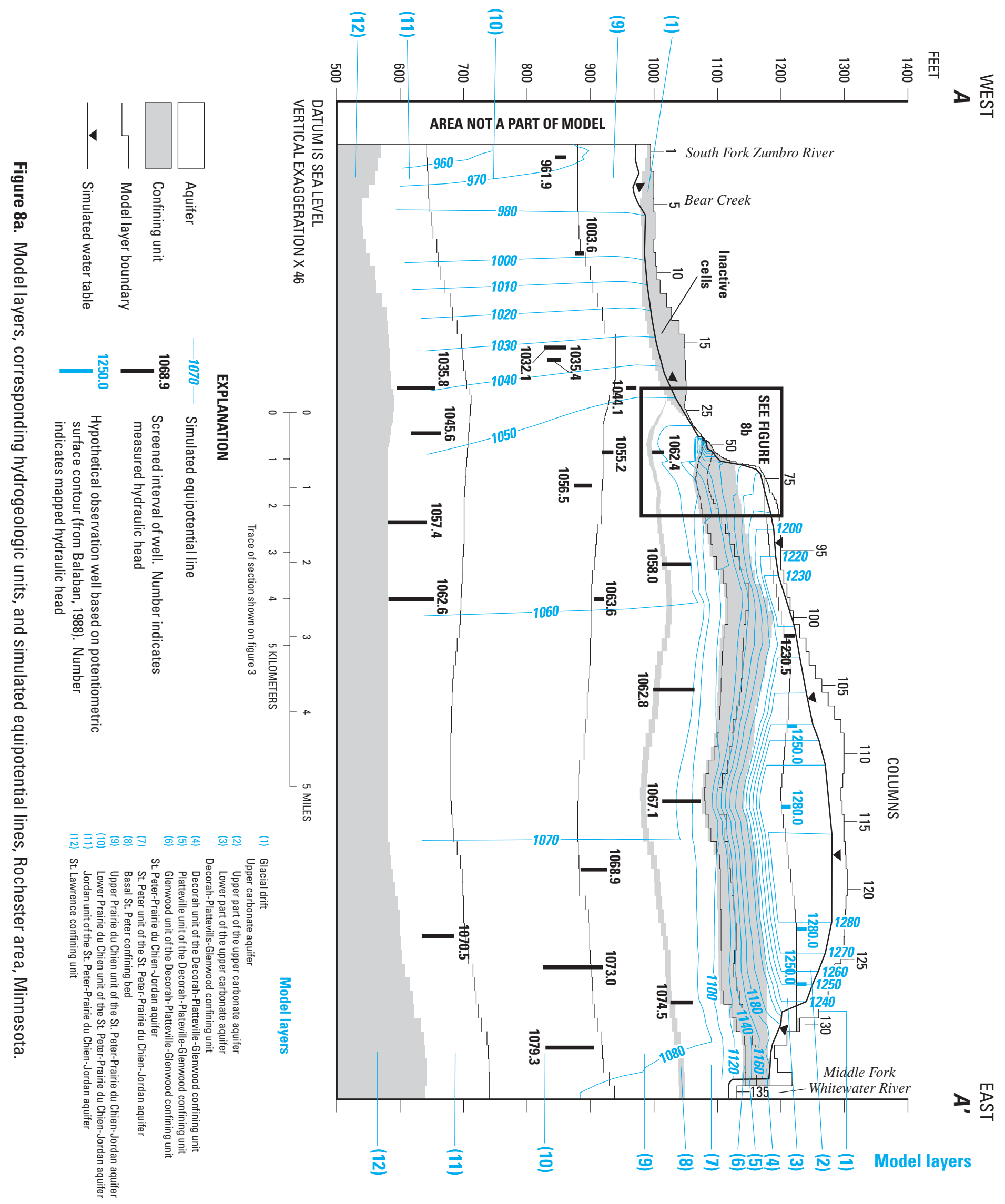




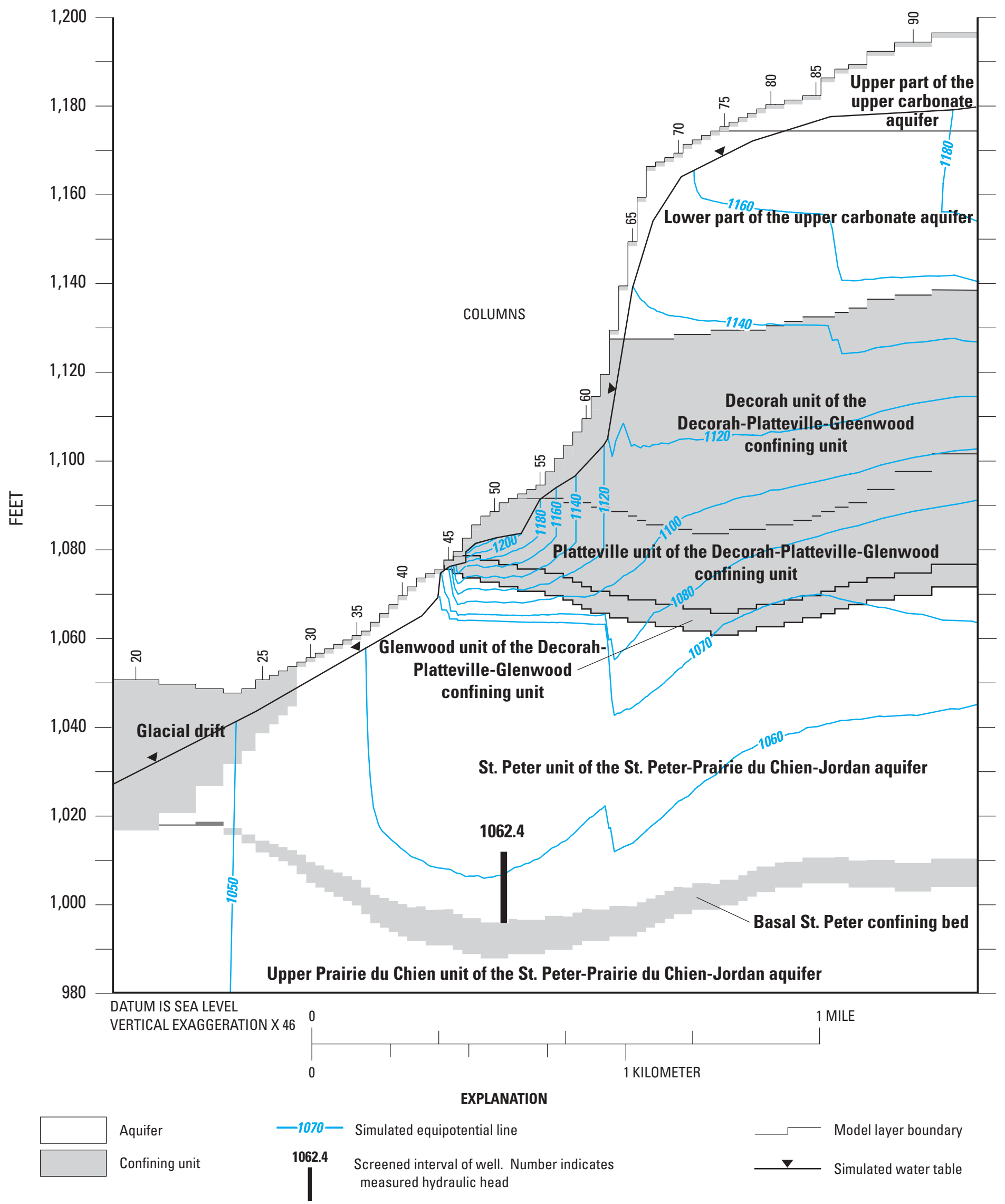

Figure 8b. Model layers corresponding hydrogeologic units, and simulated equipotential lines near edge of confining units, Rochester area, Minnesota. 
Table 5. Simulated water budget from the cross-sectional model of the aquifer system, Rochester area, Minnesota [Percent is percentage of total sources or of total discharges; --, no source or discharge for a budget component; $\mathrm{ft}^{3} / \mathrm{s}$, cubic feet per second]

\begin{tabular}{|c|c|c|}
\hline \multirow{2}{*}{ Budget component and model layer } & \multicolumn{2}{|c|}{ Source $\left(\mathrm{ft}^{3} / \mathrm{s}\right)$} \\
\hline & Rate & Percent \\
\hline \multicolumn{3}{|l|}{ Areal recharge } \\
\hline Layer 2 (Upper part of the upper carbonate aquifer) & 1.90 & 51.9 \\
\hline Layer 3 (Lower part of the upper carbonate aquifer) & 0.38 & 10.4 \\
\hline $\begin{array}{l}\text { Layer } 5 \text { (Platteville unit of the Decorah-Platteville- } \\
\text { Glenwood confining unit) }\end{array}$ & 0.12 & 3.3 \\
\hline $\begin{array}{l}\text { Layer } 7 \text { (St. Peter unit of the St. Peter-Prairie du Chien- } \\
\text { Jordan aquifer) }\end{array}$ & 0.35 & 9.5 \\
\hline $\begin{array}{l}\text { Layer } 9 \text { (Upper Prairie du Chien unit of the St. Peter- } \\
\text { Prairie du Chien-Jordan aquifer) }\end{array}$ & 0.68 & 18.6 \\
\hline Subtotal & 3.43 & 93.7 \\
\hline \multicolumn{3}{|l|}{ Leakage from streams to the aquifer } \\
\hline $\begin{array}{l}\text { Layer } 7 \text { (St. Peter unit of the St. Peter-Prairie du Chien- } \\
\text { Jordan aquifer) }\end{array}$ & 0.08 & 2.2 \\
\hline $\begin{array}{l}\text { Layer } 9 \text { (Upper Prairie du Chien unit of the St. Peter- } \\
\text { Prairie du Chien-Jordan aquifer) }\end{array}$ & 0.15 & 4.1 \\
\hline Subtotal & 0.23 & 6.3 \\
\hline Total & 3.66 & 100.0 \\
\hline \multirow[t]{2}{*}{ Budget component and model layer } & \multicolumn{2}{|l|}{ Discharge $\left(\mathrm{ft}^{3} / \mathrm{s}\right)$} \\
\hline & Rate & Percent \\
\hline \multicolumn{3}{|l|}{ Pumpage } \\
\hline $\begin{array}{l}\text { Layer } 11 \text { (Jordan unit of the St. Peter-Prairie du Chien- } \\
\text { Jordan aquifer) }\end{array}$ & 1.11 & 30.3 \\
\hline \multicolumn{3}{|l|}{ Outflow through springs and seeps } \\
\hline Layer 2 (Upper part of the upper carbonate aquifer) & 1.50 & 41.0 \\
\hline Layer 3 (Lower part of the upper carbonate aquifer) & 0.73 & 20.0 \\
\hline Subtotal & 2.23 & 61.0 \\
\hline \multicolumn{3}{|l|}{ Leakage from the aquifer to streams } \\
\hline $\begin{array}{l}\text { Layer } 9 \text { (Upper Prairie du Chien unit of the St. Peter- } \\
\text { Prairie du Chien-Jordan aquifer) }\end{array}$ & 0.32 & 8.7 \\
\hline Total & 3.66 & 100.0 \\
\hline
\end{tabular}

ground-water withdrawals by highcapacity wells. The horizontal hydraulic conductivity of the Jordan unit affects the amount of water available to the simulated pumped well, and therefore the amount of water induced to leak downward from the South Fork Zumbro River.

Discharge to springs and seeps is greatly affected by variations in simu- lated areal recharge rates to the upper carbonate aquifer (recharge zones 4 and 5), but is minimally affected by the other variations. All but a small portion of the areal recharge that entered the aquifer is discharged through springs and seeps, rather than leaking downward through the underlying relatively impermeable Decorah unit.

\section{GROUND-WATER FLOWPATHS AND TRAVEL TIMES}

The simulated flowpath lines (figs. 9-11) indicate that nearly all of the areal recharge entering the aquifer system through the upper carbonate aquifer (layers 2 and 3 ) discharges by springs and seeps (represented as 
Table 6. Simulated leakage between model layers from the cross-sectional model of the aquifer system, Rochester area, Minnesota [--, movement of water through the boundary was only downward, with no upward component of flow; $\mathrm{ft}^{3} / \mathrm{s}$; cubic feet per second; <, less than]

\begin{tabular}{|c|c|c|}
\hline \multirow{2}{*}{ Leakage between model layers } & \multirow{2}{*}{$\begin{array}{c}\text { Source } \\
\left(\mathrm{ft}^{3} / \mathrm{s}\right)\end{array}$} & \multirow{2}{*}{$\frac{\text { Discharge }}{\left(\mathrm{ft}^{3} / \mathrm{s}\right)}$} \\
\hline & & \\
\hline Layer 1 (Glacial drift)— Inactive & none & none \\
\hline \multicolumn{3}{|l|}{ Layer 2 (Upper part of the upper carbonate aquifer) } \\
\hline Through lower boundary & 0.5919 & 0.9786 \\
\hline \multicolumn{3}{|l|}{ Layer 3 (Lower part of the upper carbonate aquifer) } \\
\hline Through upper boundary & 0.9786 & 0.5919 \\
\hline Through lower boundary & -- & 0.0265 \\
\hline \multicolumn{3}{|c|}{ Layer 4 (Decorah unit of the Decorah-Platteville-Glenwood confining unit) } \\
\hline Through upper boundary & 0.0265 & -- \\
\hline Through lower boundary & $<0.0000$ & 0.0572 \\
\hline \multicolumn{3}{|c|}{ Layer 5 (Platteville unit of the Decorah-Platteville-Glenwood confining unit) } \\
\hline Through upper boundary & 0.0572 & $<0.0000$ \\
\hline Through lower boundary & 0.0013 & 0.1659 \\
\hline \multicolumn{3}{|c|}{ Layer 6 (Glenwood unit of the Decorah-Platteville-Glenwood confining unit) } \\
\hline Through upper boundary & 0.1659 & 0.0013 \\
\hline Through lower boundary & 0.0013 & 0.2119 \\
\hline \multicolumn{3}{|c|}{ Layer 7 (St. Peter unit of the St. Peter-Prairie du Chien-Jordan aquifer) } \\
\hline Through upper boundary & 0.2119 & 0.0013 \\
\hline Through lower boundary & 0.0006 & 0.6189 \\
\hline \multicolumn{3}{|l|}{ Layer 8 (Basal St. Peter confining bed) } \\
\hline Through upper boundary & 0.6189 & 0.0006 \\
\hline Through lower boundary & 0.0006 & 0.6187 \\
\hline \multicolumn{3}{|c|}{$\begin{array}{l}\text { Layer } 9 \text { (Upper Prairie du Chien unit of the St. Peter-Prairie du Chien-Jordan } \\
\text { aquifer) }\end{array}$} \\
\hline Through upper boundary & 0.6187 & 0.0006 \\
\hline Through lower boundary & 0.0212 & 1.1301 \\
\hline \multicolumn{3}{|c|}{$\begin{array}{l}\text { Layer } 10 \text { (Lower Prairie du Chien unit of the St. Peter-Prairie du Chien-Jordan } \\
\text { aquifer) }\end{array}$} \\
\hline Through upper boundary & 1.1301 & 0.0212 \\
\hline Through lower boundary & 0.0084 & 1.1174 \\
\hline \multicolumn{3}{|c|}{ Layer 11 (Jordan unit of the St. Peter-Prairie du Chien-Jordan aquifer) } \\
\hline Through upper boundary & 1.1174 & 0.0084 \\
\hline Total & 5.5505 & 5.5505 \\
\hline
\end{tabular}

drains in the cross-sectional model) into local stream drainages, the Middle Fork Whitewater River drainage, or at the edge of the Decorah unit (layer 4) (figs. 9a and 9b). The flowpath lines shown in figures $9 \mathrm{a}$ and $9 \mathrm{~b}$ were generated with particles placed initially on the surface of the uppermost aquifer layer to represent the movement of water derived from infiltration of precipitation through the aquifer system. Particles were not placed in cells representing confining units because no areal recharge was simulated to confining units. These flowpath-line results support the conclusions indicated by the water budget. The simulated flowpath lines illustrate that the sources of water withdrawn by the simulated supply wells in cell $(11,2,1)$ (fig. 9a) are: (1) leakage of water from the South Fork Zumbro River, (2) leakage from the Middle Fork Whitewater Rivers, (3) areal recharge through the upper Prairie du Chien unit (layer 9) west of the Decorah-Platteville-Glenwood confining unit, and (4) areal recharge through the Platteville unit (layer 5) and St. Peter unit (layer 7). Results indicate that areal recharge to the upper Prairie du Chien moves primarily westward and discharges to Bear Creek.

The travel times for particles derived from areal recharge to reach 


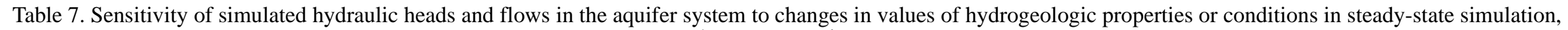
Rochester area, Minnesota

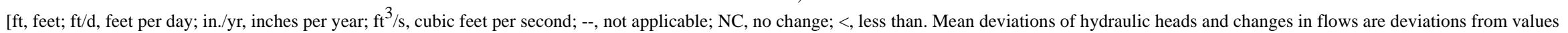
calculated by best-fit calibrated simulation. Number in parentheses is percent change in flow]

\begin{tabular}{|c|c|c|c|c|c|c|c|c|}
\hline \multirow[b]{2}{*}{$\begin{array}{l}\text { Hydrologic property } \\
\text { or condition }\end{array}$} & \multirow[b]{2}{*}{$\begin{array}{l}\text { Hydrogeologic unit and } \\
\text { model layer }\end{array}$} & \multirow{2}{*}{$\begin{array}{l}\text { Multiplied by } \\
\text { factor of (or other } \\
\text { specified } \\
\text { variation) }\end{array}$} & \multicolumn{3}{|c|}{ Hydraulic heads (ft) } & \multicolumn{3}{|c|}{ Changes in flow $\left(\mathrm{ft}^{3} / \mathrm{s}\right)$} \\
\hline & & & $\begin{array}{c}\text { Algebraic value } \\
\text { of mean } \\
\text { deviation }\end{array}$ & $\begin{array}{l}\text { Absolute value of } \\
\text { mean deviation }\end{array}$ & Range & $\begin{array}{l}\text { Stream leakage to } \\
\text { aquifer }\end{array}$ & $\begin{array}{l}\text { Aquifer leakage to } \\
\text { Bear Creek }\end{array}$ & $\begin{array}{c}\text { Discharge to } \\
\text { springs and seeps }\end{array}$ \\
\hline \multirow{2}{*}{$\begin{array}{l}{ }^{1} \text { Areal recharge to } \\
\text { zones } 1,3,4 \text { and } \\
5 \text { (in./yr) }\end{array}$} & \multirow[t]{2}{*}{--} & 2.0 & 30.12 & 30.12 & 0.02 to 39.83 & $-.1743(77.9)$ & $.5857(185)$ & $2.2579(101)$ \\
\hline & & .5 & -17.38 & 17.38 & -23.93 to -0.02 & $.1172(52.4)$ & $-.2644(83.7)$ & $-1.1266(50.5)$ \\
\hline \multirow{2}{*}{$\begin{array}{l}{ }^{1} \text { Areal recharge to } \\
\text { zone } 2 \text { (in./yr) }\end{array}$} & \multirow[t]{2}{*}{--} & 2.0 & 31.89 & 31.89 & 0.00 to 54.12 & $-.1235(55.2)$ & $.2874(91.0)$ & $.0033(0.1)$ \\
\hline & & .5 & -16.7 & 16.7 & -27.59 to 0.00 & $.0569(25.4)$ & $-.1501(47.5)$ & $-.0001(<0.1)$ \\
\hline \multirow{2}{*}{$\begin{array}{l}\text { Streambed hydraulic } \\
\text { conductivity (ft/d) }\end{array}$} & \multirow[t]{2}{*}{--} & 10.0 & 14.5 & 14.5 & 0.00 to 33.82 & $.1303(58.2)$ & $.1296(41.0)$ & $.0007(<0.1)$ \\
\hline & & .1 & -5.46 & 5.55 & -15.98 to 1.21 & $-.1802(80.6)$ & $-.1802(57.1)$ & $\mathrm{NC}$ \\
\hline \multirow{10}{*}{$\begin{array}{l}\text { Horizontal hydraulic } \\
\text { conductivity (ft/d) }\end{array}$} & \multirow{2}{*}{$\begin{array}{l}\text { Upper carbonate aquifer } \\
\text { (model layers } 2 \text { and } 3 \text { ) }\end{array}$} & ${ }^{2} 40$ & -3.03 & 3.03 & -24.32 to -0.03 & $.0006(0.3)$ & $-.0018(0.6)$ & $.0030(0.1)$ \\
\hline & & ${ }^{3} 3.0$ & 4.73 & 4.73 & 0.00 to 48.45 & $-.0018(0.8)$ & $.0046(1.5)$ & $-.0060(0.3)$ \\
\hline & $\begin{array}{l}\text { Platteville unit of the Dec- } \\
\text { orah-Platteville-Glen- } \\
\text { wood confining unit }\end{array}$ & ${ }^{4} 35$ & 0.17 & 0.3 & -1.18 to 1.05 & $.0001(<0.1)$ & $-.0003(<0.1)$ & $.0004(<0.1)$ \\
\hline & (model layer 5) & 5.1 & -0.08 & 0.11 & -0.24 to 0.35 & $\mathrm{NC}$ & $-.0002(<0.1)$ & $.0003(<0.1)$ \\
\hline & $\begin{array}{l}\text { St. Peter unit of the St. } \\
\text { Peter-Prairie du Chien- } \\
\text { Jordan aquifer }\end{array}$ & 2.0 & -0.71 & 0.76 & -3.14 to 0.31 & $\mathrm{NC}$ & $\mathrm{NC}$ & $\mathrm{NC}$ \\
\hline & (model layer 7) & .5 & 0.47 & 0.52 & -0.30 to 2.19 & $\mathrm{NC}$ & $\mathrm{NC}$ & $\mathrm{NC}$ \\
\hline & $\begin{array}{l}\text { Prairie du Chien unit of } \\
\text { the St. Peter-Prairie du } \\
\text { Chien-Jordan aquifer }\end{array}$ & 2.0 & -11.86 & 11.86 & -18.29 to 0.00 & $.0166(7.4)$ & $.0166(5.3)$ & $\mathrm{NC}$ \\
\hline & (model layers 9 and 10) & .5 & 9.11 & 9.11 & 0.00 to 13.36 & $-.0249(11.1)$ & $-.0251(7.9)$ & $.0002(<0.1)$ \\
\hline & $\begin{array}{l}\text { Jordan unit of the St. } \\
\text { Peter-Prairie du Chien- } \\
\text { Jordan aquifer }\end{array}$ & 2.0 & -29.91 & 30.37 & -56.15 to 5.07 & $-.1451(64.9)$ & $-.1088(34.5)$ & $.1510(6.8)$ \\
\hline & (model layer 11) & .5 & 30.87 & 31.58 & -9.16 to 45.01 & $.0940(42.0)$ & $.0909(28.8)$ & $.0030(0.1)$ \\
\hline \multirow{5}{*}{$\begin{array}{l}\text { Vertical hydraulic } \\
\text { conductivity (ft/d) }\end{array}$} & \multirow{2}{*}{$\begin{array}{l}\text { Decorah and Glenwood } \\
\text { units of the Decorah- } \\
\text { Platteville-Glenwood } \\
\text { confining unit }\end{array}$} & 10.0 & 0.00 & 0.00 & $\mathrm{NC}$ & $\mathrm{NC}$ & $\mathrm{NC}$ & $\mathrm{NC}$ \\
\hline & & .1 & 0.00 & 0.00 & $\mathrm{NC}$ & $\mathrm{NC}$ & $\mathrm{NC}$ & $\mathrm{NC}$ \\
\hline & (model layers 4 and 6) & & & & & & & \\
\hline & Basal St. Peter confining & 10.0 & 0.00 & 0.00 & $\mathrm{NC}$ & $\mathrm{NC}$ & $\mathrm{NC}$ & $\mathrm{NC}$ \\
\hline & bed (model layer 8) & .1 & 0.00 & 0.00 & $\mathrm{NC}$ & $\mathrm{NC}$ & $\mathrm{NC}$ & $\mathrm{NC}$ \\
\hline
\end{tabular}

${ }^{\mathrm{T}}$ Areal recharge zones shown in figures $7 \mathrm{a}$ and $7 \mathrm{~b}$.

${ }^{2}$ Upper limit of range of hydraulic conductivities reported by Kanivetsky and Walton (1979).

${ }^{3}$ Lower limit of range of hydraulic conductivities reported by Kanivetsky and Walton (1979).

${ }^{4}$ Plausible upper limit in Rochester area.

${ }^{5}$ Plausible lower limit in Rochester area. 
the three end points, or sinks, in the simulated aquifer system ranged from less than 1 year to as long as 400 years. The travel times for simulated water particles entering the upper carbonate aquifer (layers 2 and 3 ) to reach a drain cell ranged from 1 to 25 years, with most particles reaching a drain within 5 to 10 years. Water particles derived from areal recharge to the upper Prairie du Chien unit (layer 9) had maximum simulated travel times of 60-70 years before discharging to Bear Creek and from 50 to 200 years to reach the simulated supply well (fig. 9a). Water particles derived from areal recharge to the Platteville unit (layer 5) and St. Peter unit (layer 7) near the edge of the Decorah unit had simulated travel times of 125-400 years to reach the supply well.

The flowpath lines in figure 10 represent the movement of water through the St. Peter-Prairie du Chien-Jordan aquifer from the eastern regional ground-water flow divide to the west. These flowpath lines were generated with particles placed initially on the eastern model boundary. The simulated flowpath lines indicate that flow is predominantly horizontal in the St. Peter and Jordan units. Flow is predominantly vertical in the lower Prairie du Chien unit because the horizontal hydraulic conductivity is an order of magnitude lower than for the other three aquifer units (table 3 ). The simulated flowpath lines indicate both vertical and horizontal components of flow for the upper Prairie du Chien unit, which has a horizontal hydraulic conductivity lower than the St. Peter and Jordan. All the simulated flowpath lines terminate at the simulated supply well with travel times of 1,500-1,750 years.

The flowpath lines shown in figure 11 were generated with particles placed near the top of the lower part of the upper carbonate aquifer (layer 3). The simulated flowpath lines indicate that the particles flow toward and discharge to the simulated drains in the upper and lower parts of the upper carbonate aquifer (layers 2 and 3).

\section{MODEL EXPERIMENTS}

The steady-state cross-sectional model was used to investigate hypothetical variations in the representation of selected hydrogeologic units, differing areal recharge distributions, and the effects of simulated pumpage. Results of the hypothetical simulations are summarized in table 8 .

The simulation of greater hydraulic conductivity values (scenario A) resulted (1) in much lower hydraulic heads in all model columns, except in column 1, (2) large increases in leakage from the South Fork Zumbro River to the combined Prairie du Chien unit (140 percent), and (3) large increases in leakage from the combined unit to Bear Creek (66 percent) (table 8). Vertical flows within the combined unit were also increased. These effects occur because the greater simulated hydraulic conductivities for the lower Prairie du Chien (compared to those for the calibrated simulation) result in more rapid movement of water through the unit from west to east and also vertically.

Lesser hydraulic conductivity values (scenario B) conversely resulted in (1) much higher hydraulic heads, (2) large decreases in stream-aquifer leakage rates, and (3) somewhat reduced vertical flows within the combined unit of the upper Prairie du Chien. The results of scenario $\mathrm{C}$ are similar to those for scenario A, but the changes in hydraulic heads and rates of flow are of lesser magnitude.

Combining the upper and lower parts of the upper carbonate aquifer (layers 2 and 3, respectively) in simulations $\mathrm{D}$ and $\mathrm{E}$ resulted in comparatively small changes in hydraulic heads (mean absolute difference of $2.10 \mathrm{ft}$ ) and virtually no change in stream-aquifer leakage and flows through layer boundaries. The differences between the scenario D and calibrated discharge to drains for the upper and lower parts of the upper carbonate aquifer were less than $0.01 \mathrm{ft}^{3} / \mathrm{s}$. Scenario E eliminates vertical flow downward from the upper carbonate aquifer to the underlying part of the aquifer system. The results of scenario E indicate that although the rate of leakage of water downward is comparatively small $\left(0.0265 \mathrm{ft}^{3} / \mathrm{s}\right)$, the effects on hydraulic heads of eliminating this downward leakage are appreciable, with a lowering of hydraulic heads in all aquifer units by a mean of $10.95 \mathrm{ft}$.

In scenario F, the Decorah, Platteville, and Glenwood units were combined to form a single confining unit, similar to other numerical groundwater flow models (Delin, 1990; Schoenberg, 1990). Results indicate that leakage from the South Fork Zumbro River to the upper Prairie du Chien unit (layer 9) increases and discharge from the upper Prairie du Chien to Bear Creek decreases. This is due to less water being available to move through the aquifer system from east to west and ultimately discharge to Bear Creek or be withdrawn by the simulated pumped well in cell $(11,2,1)$. The change in the rate of flow downward is much greater for scenario $F$ than for scenario $E$ because no areal recharge to the Platteville (layer 5 ) is simulated in scenario F.

Scenarios $\mathrm{G}$ and $\mathrm{H}$ both indicate no change in stream-aquifer leakage due to the simulated absence of the Glenwood and basal St. Peter confining bed (table 8). Their presence has a large effect on the simulated vertical hydraulic gradient between the St. Peter unit (layer 7) and upper Prairie du Chien unit (layer 9). Scenario H indicated that the simulated difference in hydraulic heads between the two units at the nested well site located in T106NR13W, section 3 was only 0.2 $\mathrm{ft}$, whereas the measured difference in head was $7.2 \mathrm{ft}$.

The results of Scenario I indicate that a reduction in recharge of about 70 percent would result in a mean decline 


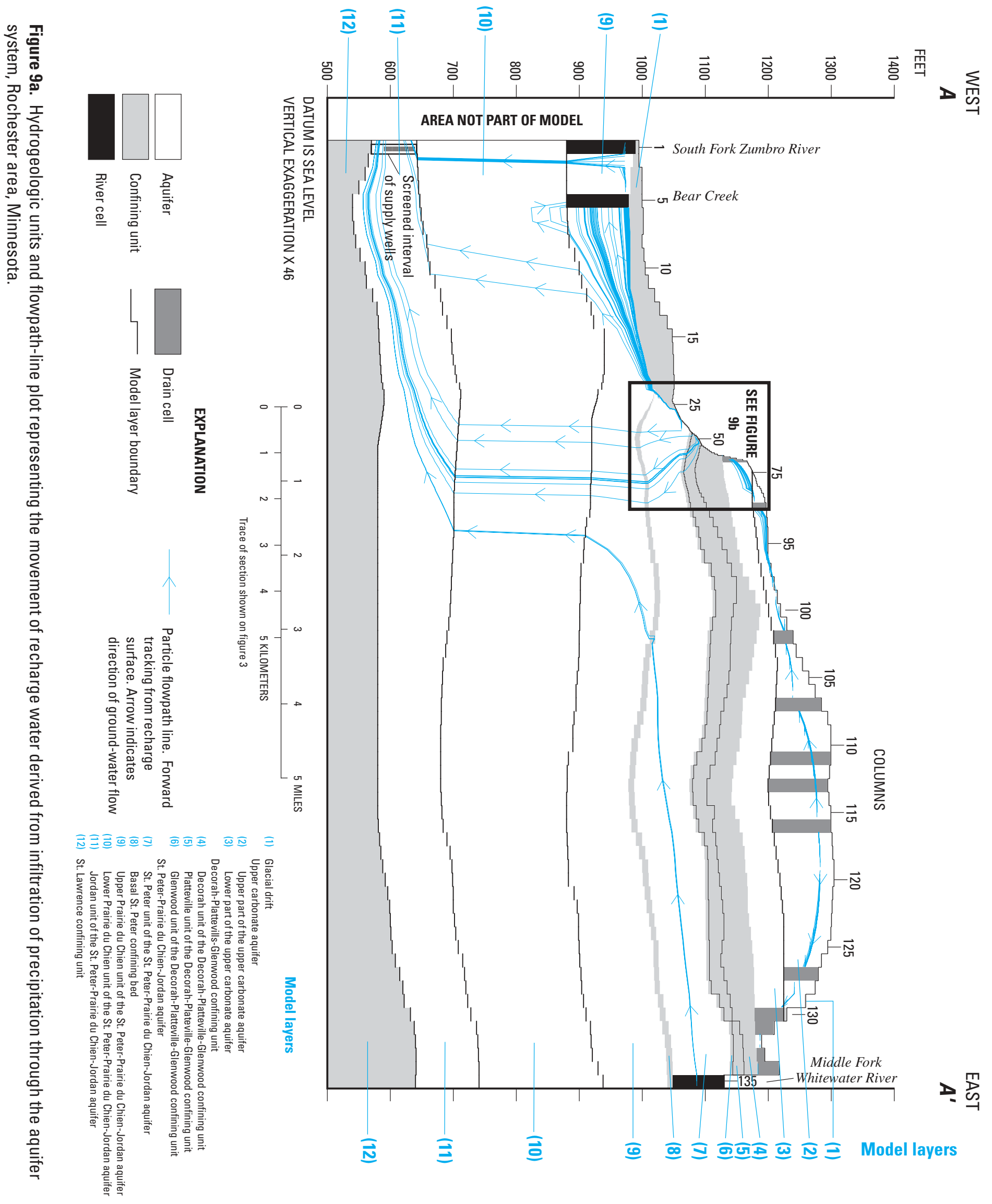




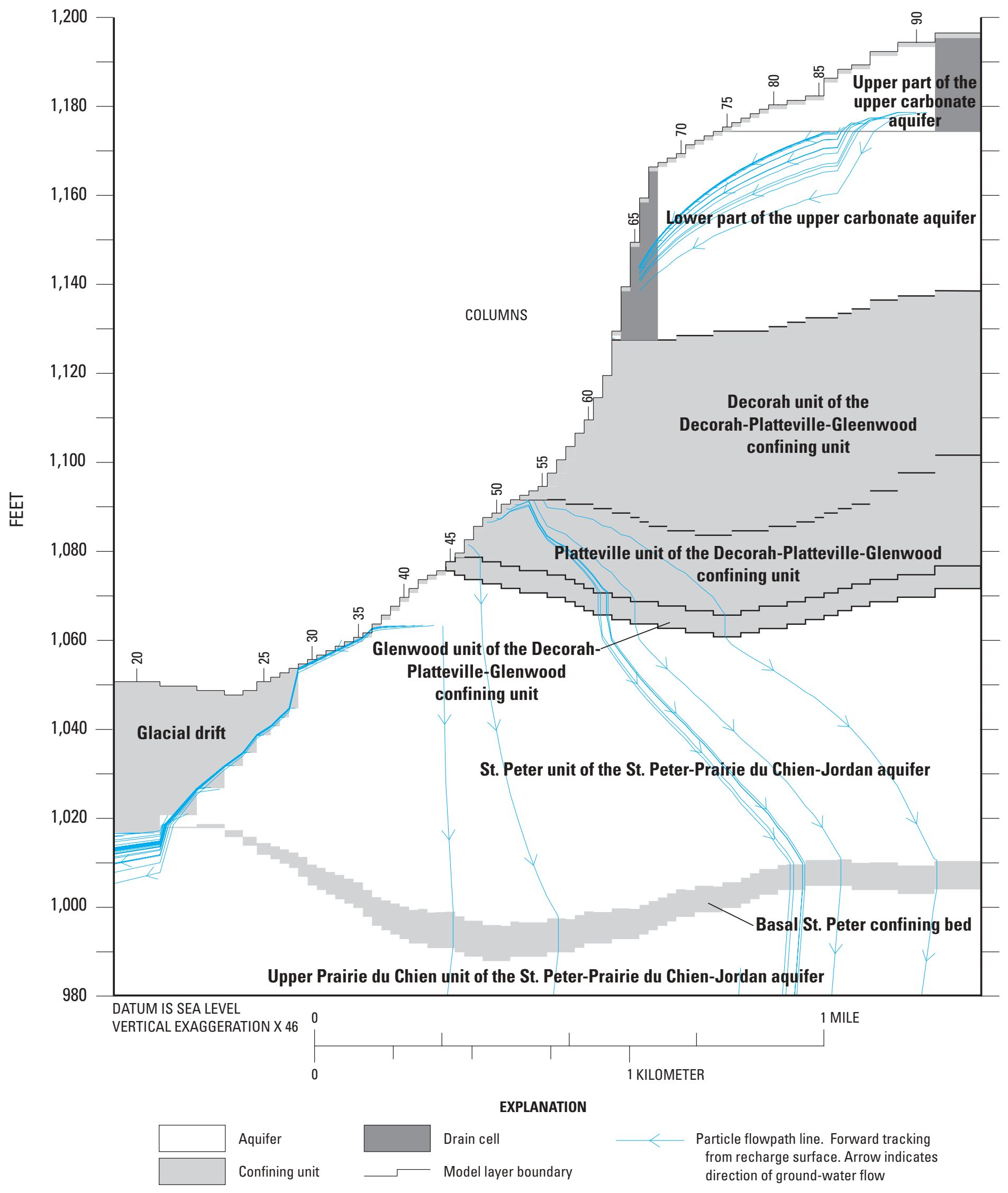

Figure 9b. Hydrogeologic units and flowpath-line plot representing the movement of recharge water derived from infiltration of precipitation through the aquifer system near edge of confining units, Rochester area, Minnesota. 


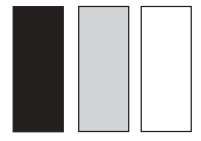

产主高高

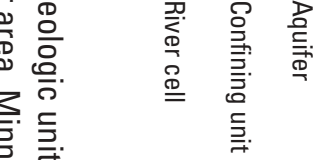

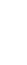

气

릉

$\stackrel{2}{3}$

음

票

(1)

音

F

三
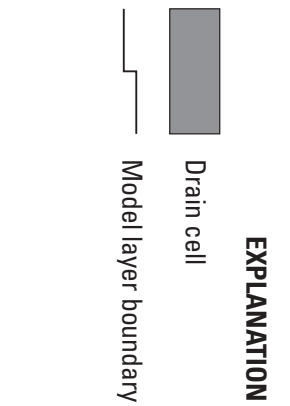

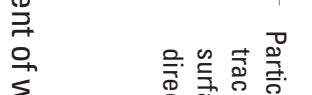

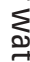

$\stackrel{\text { 票 }}{\circ}$

을

高

容.

㺉

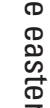

minmm!n!m

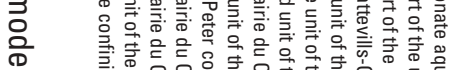

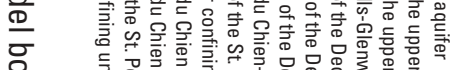

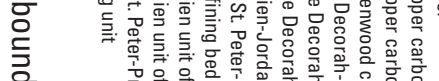

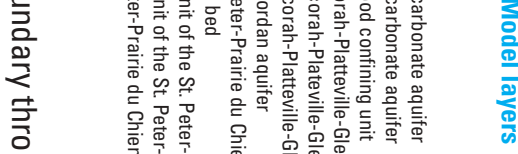

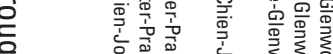

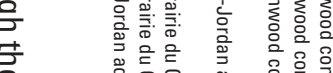

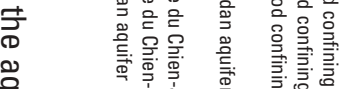

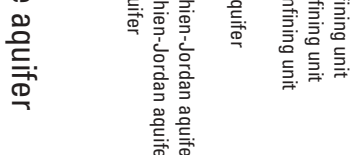
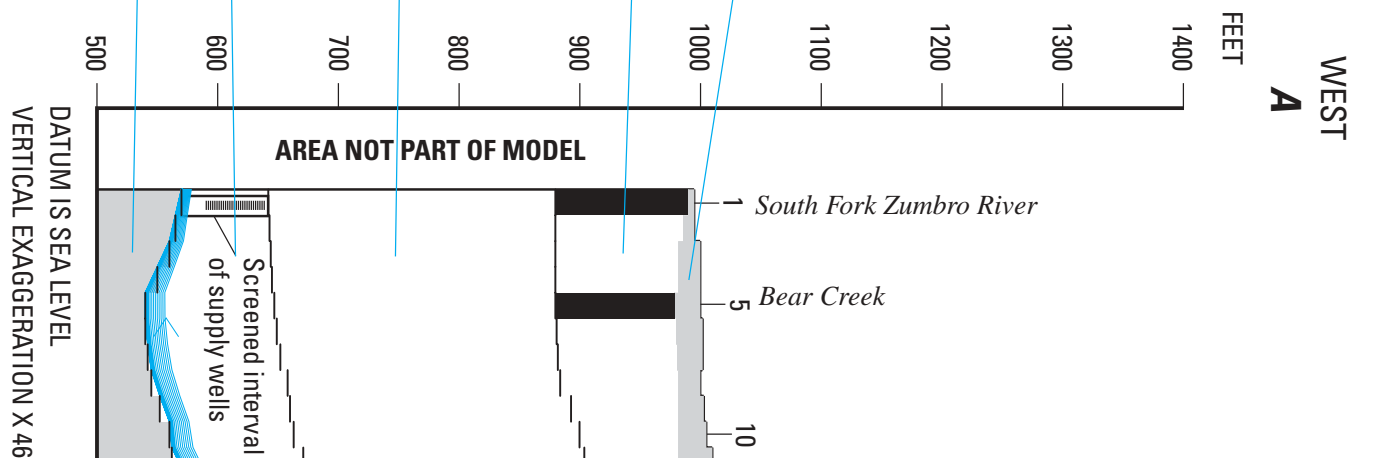

悬蒠
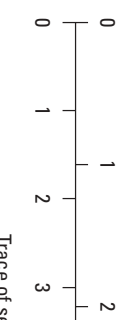

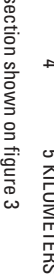

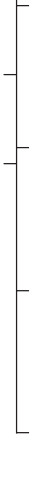


$\varsigma \mathcal{E}$

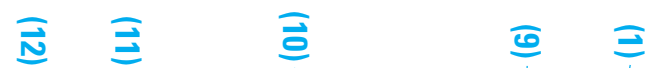

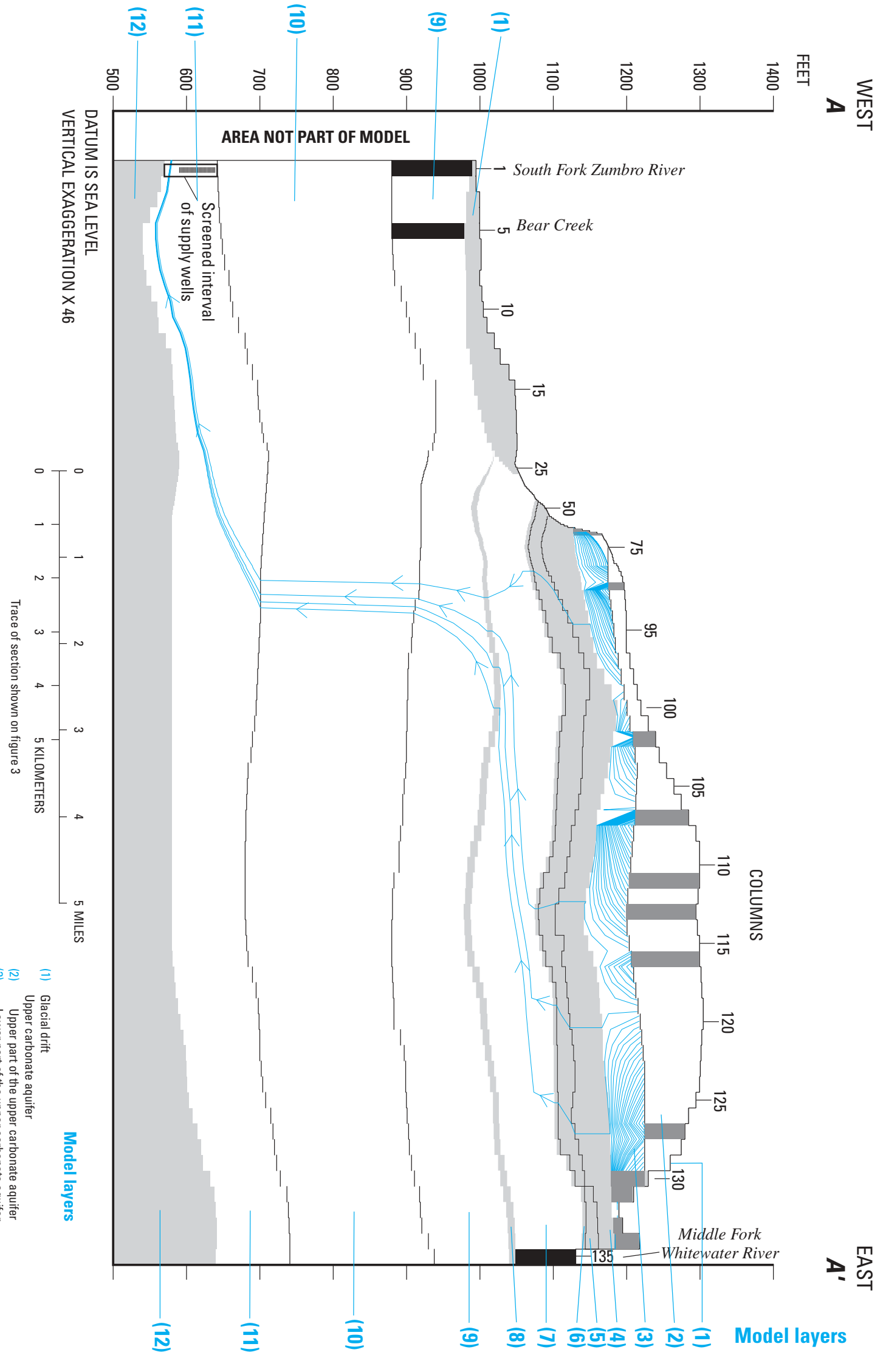


Table 3: Results for the eross=seetional model experiments, Rochester area; Minneseta

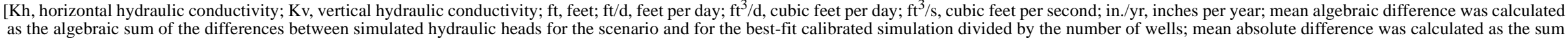

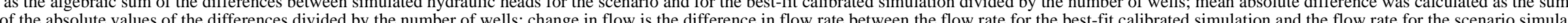
tion; NC, no change in rate of flow]

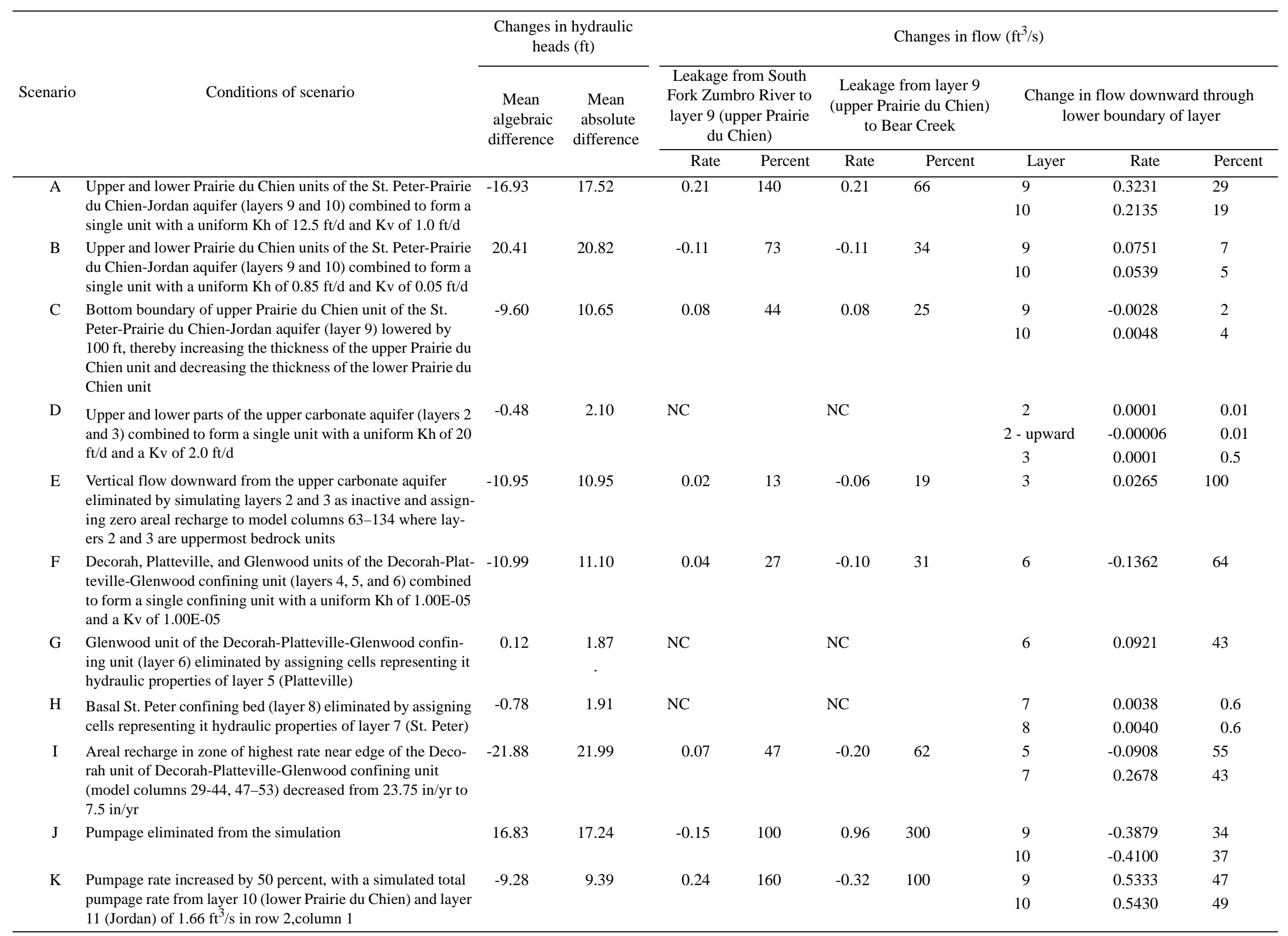


in hydraulic heads in the aquifer system of $21.99 \mathrm{ft}$ (table 8). The lower recharge rate near the edge of the Decorah resulted in less water available for discharge to Bear Creek and less water available for withdrawal by the simulated supply well.

The results of Scenario J indicate that removal of pumpage from the well would cause (1) hydraulic heads to rise an average of about $17 \mathrm{ft},(2)$ a 300 percent increase in ground-water discharge to Bear Creek, and (3) a reversal in flow directions for streamaquifer leakage for the South Fork Zumbro River (table 8). The simulated flow direction was from the upper Prairie du Chien unit to the river because ground-water pumpage was no longer lowering hydraulic heads near the river and thereby inducing downward leakage.

Results of scenario $\mathrm{K}$ indicate that a 50 percent increase in pumpage would cause (1) large declines in hydraulic heads (mean difference of $9.39 \mathrm{ft}$.), (2) large changes in streamaquifer leakage rates, and (3) large increases in rates of downward leakage through the lower boundaries of the upper and lower Prairie du Chien (layers 9 and 10, respectively) (table 8).

\section{MODEL LIMITATIONS}

A ground-water-flow model is a practical tool for simulating the response of the aquifer system to areal recharge and stresses (pumpage) on the system. A model is a simplification of a complex flow system. The accuracy of the simulations is limited by the accuracy of the data used to describe the properties of the aquifers and the confining units, areal recharge rates, pumpage, streambed-leakage coefficients, and boundary conditions. In addition, a combination of assigned inputs different from that used in a simulation could produce the same result.

Improvements in the accuracy of the various inputs to the model could enhance model accuracy. Additional information that would be beneficial includes hydraulic conductivities for the Prairie du Chien unit, spatial distribution of and variations in hydraulic conductivity, and additional hydrogeologic data for the part of the aquifer system overlying the Prairie du Chien unit.

\section{DISCUSSION OF RECHARGE AND GROUND-WATER FLOW}

The areal recharge rates derived from the three different methods of analysis are generally similar for a given aquifer unit and hydrogeologic setting (table 2). The differences in areal recharge rates for sites with estimated rates of less than $10 \mathrm{in} . / \mathrm{yr}$ are all $3.3 \mathrm{in} . / \mathrm{yr}$ or less, and for the site on the slope of the main valley in the zone of greatest recharge is $9.8 \mathrm{in} . / \mathrm{yr}$. The estimate of areal recharge derived from hydrograph analysis is greater than the estimate derived from CFC age-dating in five of the eight wells. These estimates are reasonably similar, considering the hydrograph-analysis estimates are for one year (1998) and the CFC age-dating estimates represent an average recharge rate over the period of time that water had been in the saturated zone. Both methods of analysis indicated that a much greater rate of areal recharge occurs to the St. Peter unit downslope from the edge of the Decorah-Platteville-Glenwood confining unit than occurs to the Prairie du Chien unit in any hydrogeologic setting.

The numerical-model analysis indicated that the zone of increased recharge near the edge of the DecorahPlatteville-Glenwood confining unit has an effect on flow in the aquifer system and constitutes an important source of water to high-capacity wells in the Rochester area and discharge to Bear Creek. The best-fit calibrated areal recharge value from the crosssectional model of $23.75 \mathrm{in}$./yr for the site downslope from the edge of the
Decorah-Platteville-Glenwood confining unit (Minnesota unique well number 601284) is in close agreement with the estimate of $25.5 \mathrm{in}$./yr derived from hydrograph analysis The modelsimulated discharge from the lower part of the upper carbonate aquifer (layer 3) located upslope from the confining unit (fig. 9b) was $0.21 \mathrm{ft}^{3} / \mathrm{s}$. Based on the simulated area of the slope above the confining unit, this rate of discharge represents a potential source of water of $33 \mathrm{in} . / \mathrm{yr}$ to the St. Peter, assuming a maximum groundwater evapotranspiration rate of $27 \mathrm{in./yr}$ (70 percent of the pan-evaporation rate). The rate of $33 \mathrm{in./yr}$ is similar to the estimated areal recharge rates derived from hydrograph analysis and CFC age-dating in the zone of highest recharge. The best-fit calibrated recharge value of $5.1 \mathrm{in}$./yr for the zone west of the edge of the confining unit where the Prairie du Chien unit is the uppermost bedrock unit is similar to the mean value of $5.9 \mathrm{in} . / \mathrm{yr}$ for that hydrogeologic setting derived from hydrograph analysis (table 1).

The cross-sectional model simulated leakage rates of $0.5-1.0 \mathrm{in./yr}$ where the aquifer is overlain by the Decorah-Platteville-Glenwood confining unit. By comparison, Delin (1990) calculated a rate of leakage of 0.1 in./yr, using Darcy's Law. The recharge estimates derived from hydrograph analysis were greater (as much as 2 in./yr), which may be due to pumpage effects. This leakage value may also be an order of magnitude or more too high because porosity was used in the hydrograph-analysis calculations rather than specific yield.

The calibrated model results indicated that most of the areal recharge to the upper carbonate aquifer discharges to springs and seeps (drains), with minimal leakage downward through the Decorah. The effect of the zone of increased recharge is indicated by simulated leakage rates between the units of the St. Peter-Prairie du Chien-Jor- 
dan aquifer that are approximately 10 times greater near the edge of the Decorah than they are more distant from the edge. The amount of water withdrawn by pumped wells or discharged to Bear Creek is derived predominantly from areal recharge near the edge of the Decorah $\left(0.47 \mathrm{ft}^{3} / \mathrm{s}\right)$, rather than from water that has leaked downward through the Decorah $\left(0.03 \mathrm{ft}^{3} / \mathrm{s}\right)$. Model results indicate that $0.21 \mathrm{ft}^{3} / \mathrm{s}$ discharges from the upper carbonate aquifer through springs and seeps and subsequently infiltrates into the $\mathrm{St}$. Peter downslope from the Decorah. Decreasing the simulated areal recharge rate downslope from the Decorah (23.75 in./yr) to the same simulated rate as for upslope from the Decorah (7.5 in./yr) (scenario I)

\section{SUMMARY}

The primary source of ground water for the city of Rochester, Olmsted County, southeastern Minnesota is the St. Peter-Prairie du Chien-Jordan aquifer. Based on results of a previous U.S. Geological Survey investigation in the Rochester area, relatively high rates of areal recharge to the St. Peter-Prairie du Chien-Jordan aquifer occur along the edge of the overlying Decorah-Platteville-Glenwood confining unit. The primary source of water to the zone of increased recharge along the edge of the confining unit is the upper carbonate aquifer.

Ground-water recharge rates to the three units comprising the St. Peter-Prairie du Chien-Jordan aquifer were estimated from water-level measurements using the method of hydrograph analysis. The estimated ground-water recharge rates to the aquifer during all of 1998 ranged from 1.9 to $25.5 \mathrm{in}$./yr. Recharge rates decreased with depth of the aquifer unit in a similar hydrogeologic setting. Recharge rates were greatest near the edge of the confining unit (with means as great as $13.8 \mathrm{in./yr}$ ) and least where the confining unit is thick and overlain by the upper carbonate aquifer (mean of $2.0 \mathrm{in./yr}$ ). Recharge rates downslope from the edge of the confining unit were greatest to the St. Peter on the slope of the South Fork Zumbro River Valley (as much as $25.5 \mathrm{in./yr}$ ). Results of ground-water age dating using chlorofluorocarbons (CFCs) indicated recharge dates ranging from (1) the mid-1950's to the early 1990's for the St. Peter, (2) the late 1960's to approximately 1990 for the Prairie du Chien, and (3) the early to mid-1950's for the Jordan.

The estimated areal recharge rates derived from hydrograph analysis and from CFC age-dating were in good flow downward through the lower boundary and less water available to the lower part of the aquifer system. The simulation that, in effect, eliminated the Glenwood unit of the Decorah-Platteville-Glenwood confining unit (scenario $\mathrm{G}$ ) resulted in an increase of 43 percent in flow downward through the lower boundary, but virtually no change in simulated stream-aquifer leakage. The reason for the difference in stream-aquifer leakage between scenarios $F$ and $G$ is that for scenario $\mathrm{F}$ no areal recharge was simulated to the Platteville, further illustrating the appreciable effects of the zone of increased areal recharge on flow in the aquifer system. agreement. The differences in areal recharge rates for sites with estimated rates of less than $10 \mathrm{in} . / \mathrm{yr}$ were all $3.3 \mathrm{in./yr}$ or less, and for the site on the slope of the main valley in the zone of greatest recharge was $9.8 \mathrm{in} . / \mathrm{yr}$. The best-fit calibrated model areal recharge value of $23.75 \mathrm{in} . / \mathrm{yr}$ is in close agreement with the estimate of $25.5 \mathrm{in}$./yr derived from hydrograph analysis for the site downslope from the edge of the Decorah-Platteville-Glenwood confining unit in the zone of increased areal recharge. The model-simulated discharge from springs and seeps in the lower part of the upper carbonate aquifer $\left(0.21 \mathrm{ft}^{3} / \mathrm{s}\right)$ located upslope from the confining unit represents a potential source of water of $33 \mathrm{in} . / \mathrm{yr}$ to the St. Peter. The rate of $33 \mathrm{in} . / \mathrm{yr}$ is similar to the estimated areal recharge rates derived from hydrograph analysis and CFC age-dating.

Predominantly horizontal flow occurs in the upper carbonate and St. Peter-Prairie du Chien-Jordan aquifers and predominantly vertical flow occurs through the DecorahPlatteville-Glenwood confining unit separating the aquifers. Hydraulic heads in the upper carbonate aquifer are approximately $200 \mathrm{ft}$ higher than in the St. Peter-Prairie du ChienJordan aquifer. The large vertical gradients indicate that water from the upper carbonate aquifer will move vertically downward where the Decorah-Platteville-Glenwood confining unit contains any joints or other pathways open to the St. Peter-Prairie du Chien-Jordan aquifer.

A numerical cross-sectional ground-water-flow model was constructed and calibrated for steady-state conditions. Along the flowpath, areal recharge accounts for 93.7 percent of the of the sources of water to the aquifer system. Most of the areal recharge enters the aquifer system through 
the upper carbonate aquifer ( 66.5 percent) and through the upper Prairie du Chien unit (19.9 percent). Although the amount of areal recharge entering the aquifer system near the edge of the Decorah unit through the Platteville (3.3 percent) and St. Peter (9.5 percent) is much less than through the upper carbonate aquifer, the recharge is occurring over a much smaller land surface area, and in that context is disproportionately large.

The largest simulated discharge from the aquifer system is outflow through springs and seeps from the upper carbonate aquifer (61.0 percent). Of the $2.28 \mathrm{ft}^{3} / \mathrm{s}$ of areal recharge that enters the upper carbonate aquifer, $2.23 \mathrm{ft}^{3} / \mathrm{s}$ is discharged from the aquifer by springs and seeps, leaving only $0.05 \mathrm{ft}^{3} / \mathrm{s}$ (2.2 percent) to leak downward to the underlying part of the aquifer system.

A particle-tracking program MODPATH was used to compute ground-water flowpath lines based on output from the calibrated steady-state cross-sectional model. The simulated flowpath lines indicate that nearly all of the areal recharge entering the aquifer system through the upper carbonate aquifer discharges by springs and seeps into local stream drainages, the Middle Fork Whitewater River drain age, or at the edge of the Decorah unit. The simulated flowpath lines indicate that areal recharge entering the aquifer system through the Platteville and St. Peter near the edge of the Decorah moves primarily vertically downward to the Jordan and then horizontally to the simulated supply well.

The calibrated steady-state cross-sectional model was used to investigate hypothetical variations in the representation of selected hydrogeologic units, differing areal recharge distributions, and the effects of simulated pump- age. Combining the upper and lower parts of the upper carbonate aquifer (Scenario D) resulted in comparatively small changes in hydraulic heads (mean absolute difference of $2.10 \mathrm{ft}$ ) and virtually no change in stream-aquifer leakage and flows through layer boundaries.

The hydraulic properties of the Decorah-PlattevilleGlenwood confining unit have an affect on flow in the aquifer system. Simulating the confining unit with uniform low hydraulic conductivities resulted in a reduction of 64 percent in leakage through the bottom of the confining unit. The simulation in effect eliminating the Glenwood part of the Decorah-Platteville-Glenwood confining unit resulted in a 43 percent increase in flow through the bottom of the layer. A simulated scenario indicated that although the basal St. Peter confining bed has minimal effect on flows in the aquifer system, the confining bed has a large effect on the simulated vertical hydraulic gradient between the St. Peter and upper Prairie du Chien units of the St. Peter-Prairie du Chien-Jordan aquifer.

The cross-sectional model simulations indicated that the amount of water withdrawn by pumped wells or discharged to Bear Creek is derived predominantly from areal recharge near the edge of the Decorah-Platteville-Glenwood confining unit $\left(0.47 \mathrm{ft}^{3} / \mathrm{s}\right)$, rather than from water that has leaked downward through the unit $\left(0.03 \mathrm{ft}^{3} / \mathrm{s}\right)$. Decreasing the simulated areal recharge rate downslope from the Decorah ( $23.75 \mathrm{in} . / \mathrm{yr}$ ) to the same simulated rate as for upslope from the Decorah (7.5 in./yr) resulted in a 47 percent increase in leakage from the South Fork Zumbro River to the upper Prairie du Chien and a 62 percent decrease in leakage from the upper Prairie du Chien unit to Bear Creek. 


\section{REFERENCES CITED}

Baker, D.G., and Kuehnast, E.A., 1978, Climate of Minnesota Part

$\mathrm{X}$, Precipitation normals for 1941-70: Minnesota Agricultural Experiment Station Technical Bulletin 314, $15 \mathrm{p}$.

Balaban, N.H., ed., 1988, Geologic atlas of Olmsted County, Minnesota: Minnesota Geological Survey County Atlas Series, Atlas C3,9 sheets.

Busenberg, E., and Plummer, L.N., 1992, Use of chlorofluorocarbons $\left(\mathrm{CCl}_{3} \mathrm{~F}\right.$ and $\left.\mathrm{CCl}_{2} \mathrm{~F}_{2}\right)$ as hydrologic tracers and age dating tools-The alluvium and terrace system of central Oklahoma: Water Resources Research, v. 28, p. 2257-2283.

Busenberg, E., Weeks, E.P., Plummer, L.N., and Bartholemay, R.C., 1993, Age dating ground water by use of chlorofluorocarbons $\left(\mathrm{CCl}_{3} \mathrm{~F}\right.$ and $\left.\mathrm{CCl}_{2} \mathrm{~F}_{2}\right)$, and distribution of chlorofluorocarbons in the saturated zone, Snake River Plain aquifer, Idaho National Engineering Laboratory, Idaho: U.S. Geological Survey Water-Resources Investigations Report 93-4054, $47 \mathrm{p}$.

Delin, G.N., 1987, Evaluation of availability of water from drift aquifers near the Pomme de Terre and Chippewa Rivers, western Minnesota: U.S. Geological Survey Water-Resources Investigation Report 86-4321, 53 p. 1988 , Simulation of groundwater development on water levels in glacial-drift aquifers in the Brooten-Belgrade area, west-central Minnesota: U.S. Geological Survey Water-Resources Investigation Report 88-4193, 67 p. 1990, Hydrogeology and simulation of ground-water flow in the Rochester area, southeastern Minnesota, 1987-88: U.S. Geological Survey Water-Resources Investigation Report 90-4081, 102 p.
Delin, G.N., and Almendinger, J.E., 1991, Delineation of recharge areas for selected wells in the St. Peter-Prairie du Chien-Jordan aquifer, Rochester, Minnesota: U.S. Geological Survey Open-File Report 90-397, 60 p.

Delin, G.N., and Woodward, D.G., 1984, Hydrogeologic setting and the potentiometric surfaces of regional aquifers in the Hollandale Embayment, southeastern Minnesota, 1970-80: U.S. Geological Survey Water-Supply Paper 2219, $56 \mathrm{p}$.

Dunkle, S.A., Plummer, L.N., Busenberg, E., Phillips, P.J., Denver, J.M., Hamilton, P.A., Michel, R.L., and Coplen, T.B., 1993, Chlorofluorocarbons $\left(\mathrm{CCl}_{3} \mathrm{~F}\right.$ and $\mathrm{CCl}_{2} \mathrm{~F}_{2}$ ) as dating tools and hydrologic tracers in shallow ground water of the Delmarva Peninsula, Atlantic Coastal Plain, United States: U.S. Geological Survey Water Resources Research, v. 29, p. 3837-3860.

Freeze, R.A., and Cherry, J.A., 1979, Groundwater: Prentice-Hall, Inc., Englewood Cliffs, New Jersey, $604 \mathrm{p}$.

Guiguer, N., and Franz, T., 1994, Visual MODFLOW user's manual, ver. 2.6: Waterloo Hydrogeologic Inc., Waterloo, Ontario, Canada, $311 \mathrm{p}$.

Hult, M.F., and Schoenberg, M.E., 1984, Preliminary evaluation of ground-water contamination by coal-tar derivatives, St. Louis Park, Minnesota: U.S. Geological Survey Water-Supply Paper 2211, $53 \mathrm{p}$.

Kanivetsky, Roman, and Walton, Matt, 1979, Hydrogeologic map of Minnesota, bedrock hydrogeology: Minnesota Geological Survey State Map Series S-2, 11 p.

Liesch, B.A., 1973, Ground-water investigation for the Minnesota Highway Department at the Minnehaha Park Tunnel: State Project
No. 2724-48, Minneapolis, Minnesota, $131 \mathrm{p}$.

Lindgren, R.J., 1990, Simulation of ground-water flow in the Prairie du Chien-Jordan and overlying aquifers near the Mississippi River, Fridley, Minnesota: U.S. Geological Survey Water-

Resources Investigations Report 90-4165, $152 \mathrm{p}$.

1995, Hydrogeology and groundwater flow of the drift and Platteville aquifer system, St. Louis Park, Minnesota: U.S. Geological Survey Water-Resources Investigations Report 94-4204, 79 p. 1996, Availability and quality of water from the drift aquifers in Marshall, Pennington, Polk, and Red Lake Counties, northwestern Minnesota: U.S. Geological Survey Water-Resources Investigations Report 95-4201, 144 p. 1997, Hydraulic properties and ground-water flow in the St. PeterPrairie du Chien-Jordan aquifer, Rochester area, southeastern Minnesota: U.S. Geological Survey Water-Resources Investigations Report 97-4015, 38 p.

Lindgren, R.J., and Landon, M.K., 2000, Effects of ground-water withdrawals on the Rock River and associated valley aquifer, eastern Rock County, Minnesota: U.S. Geological Survey WaterResources Investigations Report 99-4157, 103 p.

McDonald, M.G., and Harbaugh, A.W., 1988, A modular threedimensional finite-difference ground-water flow model: U.S. Geological Survey Techniques of Water-Resources Investigations, book 6 , chap. A1, $586 \mathrm{p}$.

Meyer, A.A., 1933, The flow of underground water and the field of artesian wells, in Bass, Frederic, Meyer, A.A., and Norling, S.A., Supplementary report of the Minneapolis Water Supply Commission to the City Council. 
Miller R.T., 1984, Anisotrophy in the Ironton and Galesville Sandstones near a thermal-energy-storage well, St. Paul, Minnesota: Ground Water, v. 22, no. 5, p. 532-537.

Norvitch, R.F., Ross, T.G., and Brietkrietz, Alex, 1974, Waterresources outlook for the Minneapolis-St. Paul Metropolitan area: Metropolitan Council of the Twin Cities, 219 p.

Pollock, D.W., 1989, Documentation of computer programs to compute and display pathlines using results from the U.S. Geological Survey modular three-dimensional finitedifference ground-water flow model: U.S. Geological Survey Open-File Report 89-381, 188 p.

Rasmussen, W.C., and Andreasen, G.G., 1959, Hydrologic budget of the Beaver Dam Creek Basin, Maryland: U.S. Geological Survey Water-Supply Paper 1472, $106 \mathrm{p}$.

Runkel, A.C., 1994a, Revised stratigraphic nomenclature for the Upper Cambrian (St. Croixan)
Jordan Sandstone, southeastern Minnesota, in Southwick, D.L. ed., Short contributions to the geology of Minnesota: Minnesota Geological Survey Report of Investigations 43, p. 60-71. 1994b, Deposition of the uppermost Cambrian (Croixan) Jordan Sandstone, and the nature of the Cambrian-Ordivician boundary in the Upper Mississippi Valley: Geological Society of America Bulletin, v. 106, p. 492-506 1996, Geologic investigations applicable to ground-water management, Rochester metropolitan area, Minnesota: Minnesota Geological Survey Open-File Report 96-1, 27 p.

Schoenberg, M.E., 1990, Effects of present and projected groundwater withdrawals on the Twin Cities aquifer system, Minnesota: U.S. Geological Survey WaterResource Investigations Report 90-4001, 165 p.

Smith, S.E., and Nemetz, D.A., 1996, Water quality along selected flow paths in the Prairie du Chien-Jordan aquifer, southeastern Minnesota: U.S. Geological Survey Water-Resources Investigations Report 95-4115, 76 p.

Stark, J.R., and Hult, M.F., 1985, Ground-water flow in the Prairie du Chien-Jordan aquifer related to contamination by coal-tar derivatives, St. Louis Park, Minnesota: U.S. Geological Survey WaterResources Investigations Report 85-4087, 57 p.

Woodward, D.G., 1986, Hydrogeologic framework and properties of regional aquifers in the Hollandale Embayment, southeastern Minnesota: U.S. Geological Survey Hydrologic Investigations Atlas 677, 2 pls.

Yager, R.M., 1993, Estimation of hydraulic conductivity of a riverbed and aquifer system on the Susquehana River in Broome County, New York: U.S. Geological Survey Water-Supply Paper 2387, $48 \mathrm{p}$. 